\title{
Ceramic Materials for Solid Oxide Fuel Cells
}

\author{
Taroco, H. A., Santos, J. A. F., Domingues, R. Z. and Matencio, T. \\ Department of Chemistry/Universidade Federal de Minas Gerais
}

Brasil

\section{Introduction}

Solid oxide fuel cells (SOFC) are environmentally friendly energy conversion systems to produce electrical energy with minimal environmental impact. They have several additional advantages over conventional power generation systems such as high power density, high energy-conversion efficiency, low emissions of $\mathrm{CO}_{2}, \mathrm{CO}, \mathrm{NO}_{x}, \mathrm{SO}_{2}$, fuel flexibility, modularity, ability to utilize high temperature exhaust for cogeneration or hybrid applications (with an efficiency up to approximately $70 \%$ in this case). (Fergus et al. 2009; Singhal \& Kendall, 2001; Taroco et al., 2009).

The single cell is composed of two electrodes (anode and cathode), an electrolyte, interconnects and sealing materials. The electrodes are porous, they exhibit an electronic conductivity and preferably also an ionic conductivity at the SOFC operating temperature. The electrolyte must be dense with good ion conducting characteristics (Badwal, 2001).

The conventional SOFC's operate at high temperature $\left(800-1000{ }^{\circ} \mathrm{C}\right)$. Currently, there is an increasing interest in the development of SOFC's operating at intermediate temperatures (IT_SOFC: $600-800^{\circ} \mathrm{C}$ ) (Badwal, 2001; Charpentier et al., 2000; Wincewicz \& Cooper, 2005). The main difficulty with SOFC's operating at intermediate temperatures is the significant decline in performance mainly due to lower ion conduction of the electrolyte, and to a strong cathode polarisation. Solutions to improve the cell performance include the use of alternative electrolyte and electrode materials, besides a decrease in the electrolyte thickness (Charpentier et al., 2000; Singhal \& Kendall, 2001; Sun et al., 2007, 2009).

On the anode (fuel electrode) side the gaseous fuel is oxidized according to equation (in the case of a hydrogen fuel): $2 \mathrm{H}_{2(\mathrm{~g})}+2 \mathrm{O}^{2-} \rightarrow 2 \mathrm{H}_{2} \mathrm{O}+4 \mathrm{e}^{-}$. The electrons flow through the external electrical circuit. On the cathode (air electrode) side, oxygen reacts with incoming electrons and ions $\mathrm{O}^{2-}$ are formed: $\mathrm{O}_{2(\mathrm{~g})}+4 \mathrm{e}^{-} \rightarrow 2 \mathrm{O}^{2-}$. The oxygen ions migrate through the electrolyte and combine with hydrogen on the anode side as schematized by the first equation (Fig. 1).Most of the electrochemical reactions occur at three-phase boundaries (TPB), which are defined as the sites where the ionic, electronic conductor and the gas phase are in contact i.e. where the electrode, the electrolyte and the gas phase are in contact. TPB characteristics have a large influence on the electrochemical performance of cell.

The ideal voltage $\left(E^{\circ}\right)$ of a single cell under open circuit $(\mathrm{OCV})$ conditions is close to $1.01 \mathrm{~V}$ at $800{ }^{\circ} \mathrm{C}$ as calculated from the Nernst equation with pure hydrogen at the anode and air at the cathode (Acres, G. , 2001). Under operation, the useful voltage output ( $V$ ), is given by: 


$$
V=E^{\circ}-I R-\eta \mathrm{c}-\eta \mathrm{a}
$$

where $I$ is the current passing through the cell, $R$ the cell resistance, $\eta c$ the cathode polarization losses and $\eta$ a the anode polarization losses, as detailed in Fig. 2 (Sun et al., 2007).

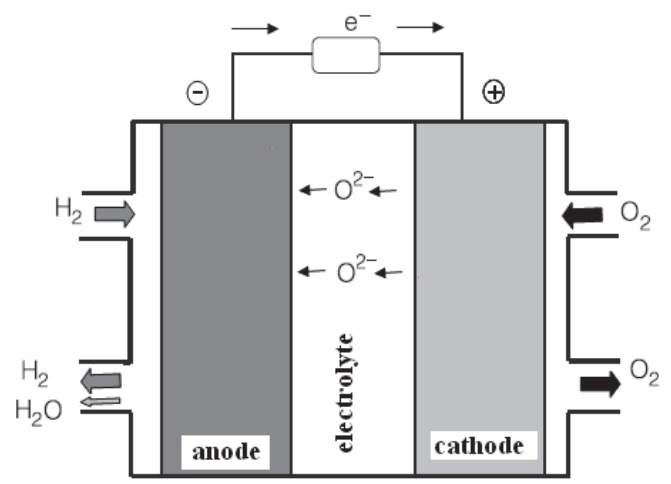

Fig. 1. Schematic of a solid oxide fuel cell (SOFC).

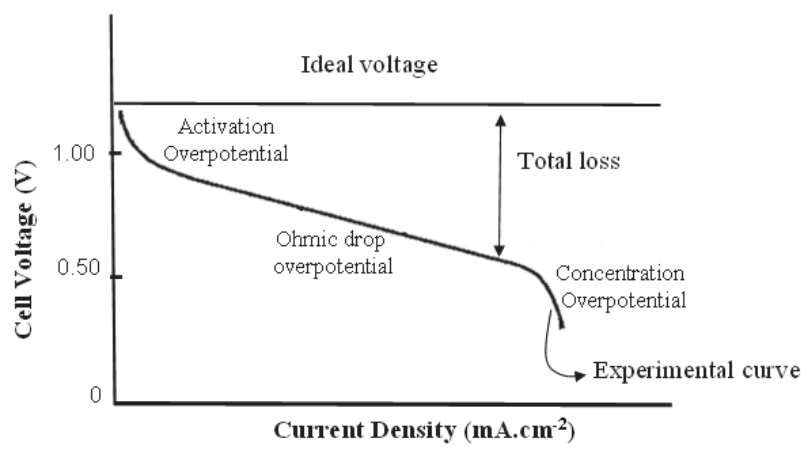

Fig. 2. Typical fuel cell voltage-current characteristic at $800{ }^{\circ} \mathrm{C}$ with pure hydrogen as fuel. (Adapted from Sun et al., 2007).

To technically characterize the overall voltage drops at each electrode, a parameter called the Area Specific Resistance (ASR) has been defined (Fabbri et al., 2008). Its use implies an approximately linear behaviour of the cell under the operating conditions.

The maximum efficiency $\left(\varepsilon_{\max }=1-\mathrm{T} \Delta \mathrm{S} / \Delta \mathrm{H}\right.$, where $\mathrm{T}$ is the temperature in Kelvin, $\Delta \mathrm{S}$ the entropy variation in Joule. $\mathrm{K}^{-1}$ and $\Delta \mathrm{H}$ the enthalpy variation in Joule) can not be achieved because of the electrode polarization losses and the material ohmic resistances. The challenge is to improve the efficiency through an optimization of the cell components and their microstructures. Nowadays an efficiency of approximately $40 \%$ can be reached.

This chapter gives emphasis on the characteristics of the main ceramic materials used as cathode, anode and electrolyte. It includes manufacturing features and techniques and electrical and microstructural characterizations of these materials. 


\section{SOFC components}

This section deals with the SOFC components: anode, cathode and electrolyte materials and their characteristics. The interconnects and sealings will not be dealt with.

\subsection{Cathode}

The cathode is the SOFC electrode where electrochemical reduction of oxygen occurs. For this, the cathode must have: (1) adequate porosity (approximately 30-40\%) to allow oxygen diffusion; (2) chemical compatibility with the other contacting components (usually the electrolyte and interconnect) under operating conditions; (3) a thermal expansion coefficient (TEC) matching those of the another components; (4) chemical and microstructure stability under an oxidizing atmosphere during fabrication and operation; (5) low cost and relatively simple fabrication procedure; (6) high catalytic activity for the oxygen reduction reaction; (7) large TPB; (8) adhesion to electrolyte surface and (9) high electronic and ionic conductivity (Fergus, et al., 2009; Singhal .\& Kendall, 2003; Sun et al., 2010).

In the Intermediate temperature Solid oxide fuel cells (IT-SOFCs), the low operating temperatures reduces the oxidative degradation, and make possible the use of metallic interconnects. On the other hand, the electrode kinetics becomes slower which results in large interfacial polarization resistances especially at the cathode. The cathode polarization losses must be minimized by an appropriate cathode material selection and an interface microstructure optimization. The choice of the cathode material is largely dependent on that of the electrolyte. Care must be taken to match the TEC's and avoid undesirable interface chemical reactions.

The cathode reaction is:

$$
\left.\left.\frac{1}{2} \mathrm{O}_{2}(\text { gas })+2 e^{-} \text {(cathode }\right) \rightarrow \mathrm{O}^{2-} \text { (electrolyte }\right)
$$

It is widely believed that the electrochemical reactions can only occur at the TPBs which are the sites where the oxygen ion conductor, electronic conductor, and the gas phase are in contact. The TPB is represented in Fig. 3:

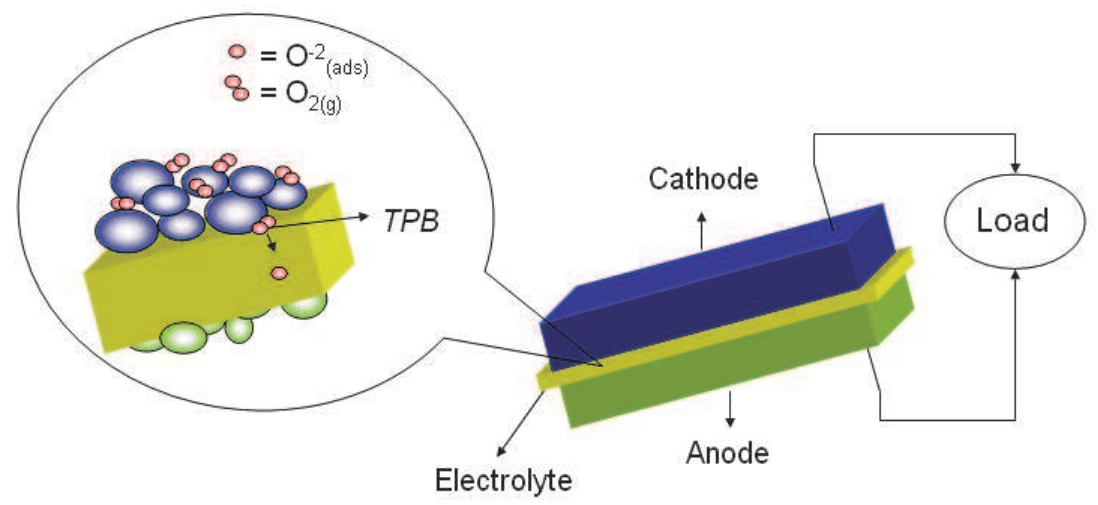

Fig. 3. Triple-phase boundaries (TPB). 
For electron-conducting perovskite-type materials the cathode reaction may occur in many steps and along different pathways depending on the electrode material. With the pure electronic conductor materials the surface pathway is the most accepted mechanism. The bulk pathway is predominant in mixed ionic electronic conductor and the electrolyte surface pathway prevails with a composite material, e.g. LSM/YSZ) (Fleig, 2003 as cited in Sun et al., 2010) as shown in Fig. 4.

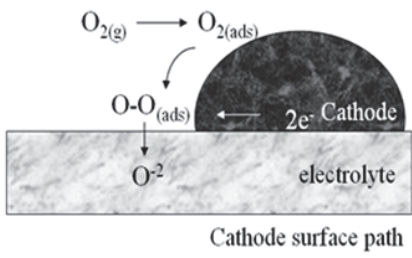

(a)

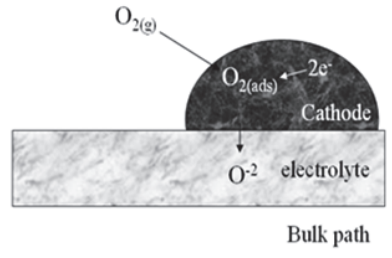

(b)

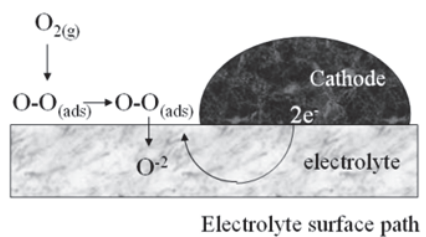

(c)

Fig. 4. TPB: Three reaction pathways of the oxygen reduction and some possible ratedetermining steps: (a) cathode surface pathway, (b) bulk pathway and (c) electrolyte surface pathway (adapted by Sun et al., 2010).

Perovskite-type oxides with general formula $\mathrm{ABO}_{3}$ are mostly used as cathode materials. The Fig. 5 shows their structure in which A and B are cations with an overall charge of +6 .
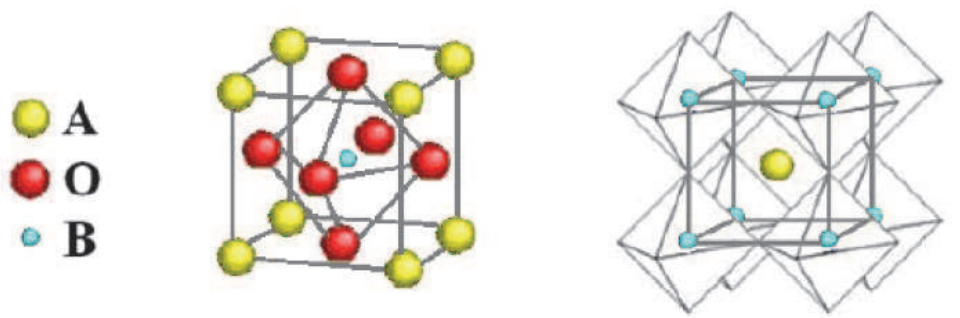

Fig. 5. Schematic representation of lattice structure of perovskite, $\mathrm{ABO}_{3}$, adapted from Guarany, 2008.

The A cations (such as, $\mathrm{La}, \mathrm{Sr}, \mathrm{Ca}, \mathrm{Pb}$, etc.) have lower valences. They are larger in size and are coordinated to twelve oxygen anions. The $\mathrm{B}$ cations (such as, $\mathrm{Ti}, \mathrm{Cr}, \mathrm{Ni}, \mathrm{Fe}, \mathrm{Co}, \mathrm{Zr}$, etc.) occupy a much smaller space and are coordinated to six oxygen anions (Singhal \& Kendall, 2003; Sun et al., 2010). 
Lanthanum manganites $\left(\mathrm{LaMnO}_{3}\right.$ : LSM) are still the most common material for high temperature SOFCs because of their compatibility with $\mathrm{ZrO}_{2} / \mathrm{Y}_{2} \mathrm{O}_{3}$ (YSZ: yttria stabilized zirconia) electrolytes (Belardi et.al; 2009; Brant, et al.; 2001, 2006; Sun et al., 2010). They can be doped on the A site by cations such as $\mathrm{Sr}^{2+}$ (at 10-20 mol \%) or $\mathrm{Ca}^{2+}$ (at 10-30 mol \%) (Singhal \& Kendall, 2003; Sun et al., 2010; Wincewicz \& Cooper, 2005). This material can be formulated as $\mathrm{La}_{1-x} \mathrm{~A}_{x} \mathrm{MnO}_{3 \pm \delta}$ (where $\mathrm{A}$ is divalent cation, "+" denotes an oxygen excess and “-“an oxygen deficiency).

In the Sr-doped lanthanum manganite $\left(\mathrm{La}_{1-x} \mathrm{Sr}_{x} \mathrm{MnO}_{3-\delta}\right.$ with $\left.\mathrm{x}<0.5\right)$ a manganese ion oxidation has been observed (Sun, et al., 2010):

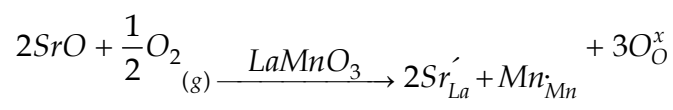

According this reaction, the Sr doping increases the electron-hole concentration and improves the electrical conductivity of the electrode material. Its crystalline structure is influenced by temperature and oxygen partial pressure (Fergus et al., 2009; Singhal \& Kendall, 2003).It is rhombohedral at room temperature while the undoped lanthanum manganites is orthorhombic (Fergus et al., 2009; Singhal \& Kendall, 2003).

LSM reacts with YSZ at temperatures above $1300{ }^{\circ} \mathrm{C}$ and unwanted electronic insulating phases like $\mathrm{La}_{2} \mathrm{Zr}_{2} \mathrm{O}_{7}$ and $\mathrm{SrZrO}_{3}$ are formed (Brant et al., 2006; Ralph et al., 2001 as cited in Wincewicz \& Cooper, 2005). The amounts of these electronically insulating phases depend on the La/Sr ratio in the LSM (Sun et al., 2010). For temperatures below $1200{ }^{\circ} \mathrm{C}$ and Sr content of $30 \mathrm{~mol} \%$, YSZ is compatible with LSM and unwanted phases are not formed (Jiang et al., 1999 as cited in Wincewicz \& Cooper, 2005).

The dopant concentration influences the TEC and electronic conductivity, according Table 1. For example, the TEC of undoped $\mathrm{LaMnO}_{3}$ is $11.2 \times 10^{-6} \mathrm{~K}^{-1}$ in the temperature range 35$1000{ }^{\circ} \mathrm{C}$ (Fergus et al., 2009; Singhal \& Kendall, 2003) while that of doped manganite (e.g. $\mathrm{La}_{1-\mathrm{x}} \mathrm{Sr}_{x} \mathrm{MnO}_{3}, \mathrm{x}: 0.05-0.30$ ) is $12.8 \times 10^{-6} \mathrm{~K}^{-1}$. The substitution of La by lower valence cations decreases the TEC. The increasing amount of dopants on the A site increases the TEC and the electronic conductivity.

Below $800{ }^{\circ} \mathrm{C}$, the $\mathrm{LaSrMnO}_{3}$ materials exhibit fairly poor catalytic activities for the oxygen reduction and their electronic conductivity is significantly reduced, so new SOFC cathode materials have to be developed for intermediate temperature operation.

Mn substitution by $\mathrm{Co}$ or Fe on $\mathrm{B}$ sites (LSCF: $\mathrm{La}_{1-x} \mathrm{Sr}_{x} \mathrm{Fe}_{1-y} \mathrm{Co}_{y} \mathrm{O}_{3-\delta}$ ) gives promising cathode materials for IT-SOFC (Sun et al., 2010). They have high electronic and ionic conductivities and excellent catalytic activity for oxygen reduction at intermediate temperatures. Moreover, these materials have a TEC similar to that of the intermediate temperature electrolytes based on Ceria.

In general, the Sr concentration on the A-site enhances the ionic conductivities while the increase of the electronic conductivities is obtained by Fe and Co doping on the B-site (Sun et al., 2010).

Table 1 shows LSCF perovskites used as cathodes. It can be seen that the A-site deficiency has only a small effect on the TEC while an increasing of Sr content results in a higher TEC due to higher oxygen vacancy concentrations. In the LSCF system, the electrical conductivity of $\mathrm{La}_{1-x} \mathrm{Sr}_{x} \mathrm{Co}_{0.2} \mathrm{Fe}_{0.8} \mathrm{O}_{3-\delta}$ increases from 87 to $333 \mathrm{Scm}^{-1}$ with an increase of $\mathrm{Sr}^{2+}$ $(x=0.2-0.4)$ at $800^{\circ} \mathrm{C}$, but the TEC also increases from $14.8 \times 10^{-6}$ to $15.3 \times 10^{-6} \mathrm{~K}^{-1}$. 
The ionic conductivity of $\mathrm{LaMnO}_{3}$ is lower than that of the YSZ electrolyte and it increases with the Mn substitution by Co.

\begin{tabular}{|c|c|c|c|}
\hline Composition & TEC $\left(\times 10^{-6} \mathrm{~K}^{-1}\right)$ & References & $\sigma_{\mathrm{e}}\left(\mathrm{Scm}^{-1}\right)$ \\
\hline $\mathrm{La}_{0,5} \mathrm{Sr}_{0,5} \mathrm{MnO}_{3-\delta}$ & $300(947)^{c}$ & $\begin{array}{c}\text { (Badwal \& Forger, } 1997 \text { as } \\
\text { cited in Florio et al., } \\
\text { 2004)o }\end{array}$ & - \\
\hline $\mathrm{La}_{0.6} \mathrm{Sr}_{0.4} \mathrm{MnO}_{3-\delta}$ & $13(800)$ & (Kenjo \& Nishiya, 1992) & 130 \\
\hline $\mathrm{La}_{0.7} \mathrm{Sr}_{0.3} \mathrm{MnO}_{3-\delta}$ & $12.8(25-1100)$ & $\begin{array}{c}\text { (Badwal \& Forger, } 1997 \text { as } \\
\text { cited in Florio et al., } \\
\text { 2004)o }\end{array}$ & $265(947)$ \\
\hline $\mathrm{La}_{0.7} \mathrm{Sr}_{0.3} \mathrm{MnO}_{3-\delta}$ & $11.7(800)$ & (Yamamoto et al., 1987) & 240 \\
\hline $\mathrm{La}_{0.8} \mathrm{Sr}_{0.2} \mathrm{MnO}_{3-\delta}$ & $11.8(900)$ & (Jiang, 2002) & 300 \\
\hline $\mathrm{La}_{0,85} \mathrm{Sr}_{0,15} \mathrm{MnO}_{3-\delta}$ & - & $\begin{array}{l}\text { (Badwal \& Forger, } 1997 \text { as } \\
\text { cited in Florio et al., 2004) }\end{array}$ & $175(947)$ \\
\hline $\mathrm{La}_{0.4} \mathrm{Sr}_{0.6} \mathrm{Co}_{0.2} \mathrm{Fe}_{0.8} \mathrm{O}_{3-\delta}$ & $16.8(600)$ & (Tai, et al,1995) & - \\
\hline $\mathrm{La}_{0.6} \mathrm{Sr}_{0.4} \mathrm{Co}_{0.8} \mathrm{Mn}_{0.2} \mathrm{O}_{3-\delta}$ & $18.1(500)$ & (Chen et al., 2003) & 1,400 \\
\hline $\mathrm{La}_{0.6} \mathrm{Sr}_{0.4} \mathrm{Co}_{0.8} \mathrm{Fe}_{0.2} \mathrm{O}_{3-\delta}$ & $21.4(800)$ & $\begin{array}{l}\text { (Petric et al., 2000; } \\
\text { Teraoka, 1991) }\end{array}$ & 269 \\
\hline $\mathrm{La}_{0.6} \mathrm{Sr}_{0.4} \mathrm{Co}_{0.2} \mathrm{Fe}_{0.8} \mathrm{O}_{3-\delta}$ & $15.3(600)$ & (Tai et al., 1995) & 330 \\
\hline $\mathrm{La}_{0.8} \mathrm{Sr}_{0.2} \mathrm{Co}_{0.2} \mathrm{Fe}_{0.8} \mathrm{O}_{3-\delta}$ & $14.8(800)$ & (Ullmann et al., 2000) & 87 \\
\hline $\mathrm{La}_{0.8} \mathrm{Sr}_{0.2} \mathrm{Co}_{0.8} \mathrm{Fe}_{0.2} \mathrm{O}_{3-\delta}$ & $19.3(800)$ & $\begin{array}{c}\text { (Ullmann et al., 2000; } \\
\text { Petric et al., 2000) }\end{array}$ & 1,000 \\
\hline $\mathrm{La}_{0.8} \mathrm{Sr}_{0.2} \mathrm{Fe}_{0.4} \mathrm{Co}_{0.6} \mathrm{O}_{3-\delta}$ & $435(1000)$ & (Tai et al., 1995) & $\begin{array}{c}20(100- \\
900)\end{array}$ \\
\hline $\mathrm{La}_{0.8} \mathrm{Sr}_{0.2} \mathrm{Fe}_{0.6} \mathrm{Co}_{0.4} \mathrm{O}_{3-\delta}$ & 305 (1000)] & (Tai et al., 1995 & $\begin{array}{c}17.6(100- \\
900)\end{array}$ \\
\hline $\mathrm{La}_{0.8} \mathrm{Sr}_{0.2} \mathrm{Fe}_{0.8} \mathrm{Co}_{0.2} \mathrm{O}_{3-\delta}$ & $150(1000)$ & (Tai et al., 1995 & $\begin{array}{l}15.4(100- \\
800)\end{array}$ \\
\hline $\mathrm{La}_{0.8} \mathrm{Sr}_{0.2} \mathrm{Mn}_{0.4} \mathrm{Co}_{0.6} \mathrm{O}_{3-\delta}$ & $255(1000)$ & (Florio et al.,2004) & $\begin{array}{l}17.2(200- \\
800)\end{array}$ \\
\hline $\mathrm{La}_{0.8} \mathrm{Sr}_{0.2} \mathrm{Mn}_{0.6} \mathrm{Co}_{0.4} \mathrm{O}_{3-\delta}$ & $125(1000)$ & $\begin{array}{c}\text { (Badwal \& Forger, } 1997 \text { as } \\
\text { cited in Florio et al., } \\
\text { 2004)o }\end{array}$ & $\begin{array}{l}16.1(200- \\
800)\end{array}$ \\
\hline $\mathrm{La}_{0.8} \mathrm{Sr}_{0.2} \mathrm{Mn}_{0.8} \mathrm{Co}_{0.2} \mathrm{O}_{3-\delta}$ & $130(1000)$ & $\begin{array}{c}\text { (Badwal \& Forger, } 1997 \text { as } \\
\text { cited in Florio et al., } \\
\text { 2004)o }\end{array}$ & $\begin{array}{l}13.9(200- \\
800)\end{array}$ \\
\hline
\end{tabular}

*In parenthesis are temperatures in ${ }^{\circ} \mathrm{C}$.

Table 1. Electronic conductivity and TEC of several solid oxide fuel cell cathodes (adapted from Florio et al., 2004 and Sun et al., 2010) 
Dutta et al., 2009 synthesized different perovskites with different dopants $\left(\mathrm{La}_{0.8} \mathrm{Sr}_{0.2} \mathrm{FeO}_{3-\delta}\right.$; $\mathrm{La}_{0.8} \mathrm{Sr}_{0.2} \mathrm{Co}_{0.8} \mathrm{Fe}_{0.2} \mathrm{O}_{3-\delta}$ and $\mathrm{La}_{0.5} \mathrm{Sr}_{0.5} \mathrm{Co}_{0.8} \mathrm{Fe}_{0.2} \mathrm{O}_{3-\delta}$ ) by a combustion synthesis technique. According to their results $\mathrm{La}_{0.5} \mathrm{Sr}_{0.5} \mathrm{Co}_{0.8} \mathrm{Fe}_{0.2} \mathrm{O}_{3-\delta}$ shows the highest electrical conductivity and superior electrochemical performance. Highest current density of approximately $1.72 \mathrm{~A} . \mathrm{cm}^{-2}$ and power density of $1.2 \mathrm{~W} . \mathrm{cm}^{-2}$ at $0.7 \mathrm{~V}$, at a operating temperature of $800{ }^{\circ} \mathrm{C}$, is obtained with this cathode composition and YSZ electrolyte $(\sim 10 \mu \mathrm{m})$ with GDC interlayer $(\sim 15 \mu \mathrm{m})$. The value of total area specific resistance (ASR) of this cathode is approximately $0.211 \mathrm{~A} . \mathrm{cm}^{2}$.

LSCF-based cathodes have a lower ASR than LSM perovskites but they are incompatible with YSZ electrolytes due to undesirable interface reactions. Therefore, Ceria based electrolytes such as gadolinia doped ceria (GDC) are used with LSCF cathodes (Uhlenbruck et al., 2009). Furthermore, the TEC values of the GDC electrolytes $\left(12.8 \times 10^{-6} \mathrm{~K}^{-1}\right)$ better match that of the LSCF's (equal or greater than $17 \times 10^{-6} \mathrm{~K}^{-1}$. ).

Many other perovskites are used as cathodes in SOFC such as: $\operatorname{Pr}_{0.5} \mathrm{Sr}_{0.5} \mathrm{FeO}_{3-\delta}$; $\mathrm{Sr}_{0.9} \mathrm{Ce}_{0.1} \mathrm{Fe}_{0.8} \mathrm{Ni}_{0.2} \mathrm{O}_{3-\delta} ; \quad \mathrm{Sr}_{0.8} \mathrm{Ce}_{0.1} \mathrm{Fe}_{0.7} \mathrm{Co}_{0.3} \mathrm{O}_{3-\delta} ; \quad \mathrm{LaNi}_{0.6} \mathrm{Fe}_{0.4} \mathrm{O}_{3-\delta} \quad(\mathrm{LNF}) ; \quad \operatorname{Pr}_{0.8} \mathrm{Sr}_{0.2} \mathrm{Co}_{0.2} \mathrm{Fe}_{0.8} \mathrm{O}_{3-\delta} ;$ $\mathrm{Pr}_{0.7} \mathrm{Sr}_{0.3} \mathrm{Co}_{0.2} \mathrm{Mn}_{0.8} \mathrm{O}_{3-\delta} ; \quad \mathrm{Pr}_{0.8} \mathrm{Sr}_{0.2} \mathrm{FeO}_{3-\delta} ; \quad \mathrm{Pr}_{0.6} \mathrm{Sr}_{0.4} \mathrm{Co}_{0.8} \mathrm{Fe}_{0.2} \mathrm{O}_{3-\delta} ; \quad \operatorname{Pr}_{0.4} \mathrm{Sr}_{0.6} \mathrm{Co}_{0.8} \mathrm{Fe}_{0.2} \mathrm{O}_{3-\delta} ;$ $\mathrm{Pr}_{0.7} \mathrm{Sr}_{0.3} \mathrm{Co}_{0.9} \mathrm{Cu}_{0.1} \mathrm{O}_{3-\delta} ; \mathrm{Ba}_{0.5} \mathrm{Sr}_{0.5} \mathrm{Co}_{0.8} \mathrm{Fe}_{0.2} \mathrm{O}_{3-\delta} ; \mathrm{Sm}_{0.5} \mathrm{Sr}_{0.5} \mathrm{CoO}_{3-\delta} ; \mathrm{LaNi}_{0.6} \mathrm{Fe}_{0.4} \mathrm{O}_{3-\delta}$ (Sun et al., 2010). Their features will not be addressed in this work.

\subsection{Electrolyte}

The electrolyte is the component of the cell responsible for conducting ions between the electrodes, for the separation of the reacting gases and for the internal electronic conduction blocking, forcing the electrons to flow through the external circuit (Singhal \& Kendall, 2001). Without significant ion conduction, no current would pass through the cell and only a potential difference would be detected. There are three types of electrolytes that differ by the ion transport mechanism: anionic, protonic and mixed ionic. However, most of the high temperature fuel cells operate via oxygen ion $\left(\mathrm{O}^{2-}\right)$ conduction from the air electrode to the fuel electrode. This conduction occurs because of the presence of oxygen ions vacancies, so the crystallites forming the electrolyte must have unoccupied anionic sites. The energy required for the oxide ion migration from one site to the neighboring unoccupied equivalent site must be small (Faro et al., 2009).

For satisfactory performance, the electrolyte must meet some requirements that limit the choice of the material. These include (EG\&G Technical services, 2000; Fergus et al., 2009; Singhal \& Kendall, 2001): (1) an oxide-ion conductivity greater than $10^{-2} \mathrm{~S}_{\mathrm{cm}} \mathrm{cm}^{-1}$ at the operating temperature; (2) negligible electronic conduction, which means an electronic transport number close to zero; (3) high density to promote gas impermeability; (4) thermodynamic stability over a wide range of temperature and oxygen partial pressure; (5) TEC compatible with that of the electrodes and other cell materials from ambient temperature to cell operating temperature; (6) suitable mechanical properties, with fracture resistance greater than $400 \mathrm{MPa}$ at room temperature; (7) negligible chemical interaction with electrode materials under operation and fabrication conditions to avoid formation of blocking interface phases; (8) ability to be elaborated as thin layers (less than $30 \mu \mathrm{m}$ ); (9) low cost of starting materials and fabrication.

Zirconia based ceramic materials have been the most investigated and developed electrolytes for high temperature use. At room temperature, pure zirconia is monoclinic. At $1170{ }^{\circ} \mathrm{C}$, it undergoes a phase transition to a tetragonal structure with a large volume 
change. Above $2370{ }^{\circ} \mathrm{C}$, pure zirconia is transformed into the cubic fluorite structure. The cubic phase still remains up to the melting point at $2680{ }^{\circ} \mathrm{C}$ as showed below (Faro et al., 2009; Fergus et al., 2009). The fluorite lattice is an interpenetration of a cubic oxygen lattice in the middle of the face-centered cubic zirconium lattice (Fig. 6).

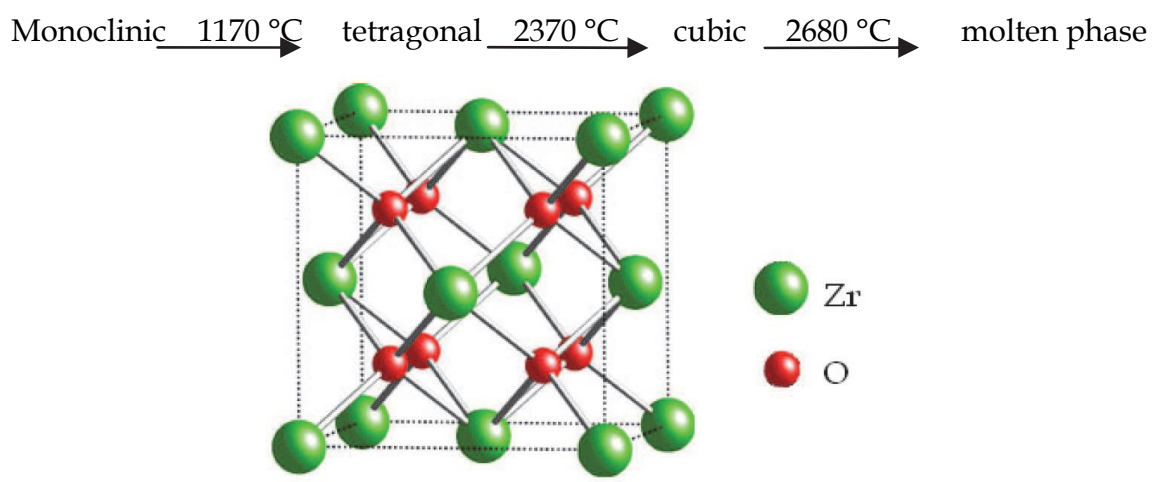

Fig. 6. Unit cell of zirconia fluorite (Adapted from Crystal Maker ${ }^{\circledR}$ Demonstration version)

Doping zirconia with aliovalent ions is a common practice to stabilize the cubic fluorite structure from room temperature up to its melting point. The doping process increases the oxygen vacancy concentration, and consequently improves the ionic conductivity. According to the Kröger-Vink notation (Mitchell, 2004) for a typical trivalent dopant, M, the oxygen vacancies formation can be represented as:

$$
\mathrm{Mn}_{2} \mathrm{O}_{3} \stackrel{\mathrm{ZrO}_{2}}{\rightarrow} 2 \mathrm{M}_{\mathrm{Zr}}^{\prime}+3 \mathrm{O}_{o}^{*}+V_{o}^{*}
$$

So oxygen vacancies doubly ionized are produced at concentrations proportional to the dopant content.

The main dopants of zirconia are $\mathrm{CaO}, \mathrm{MgO}, \mathrm{Y}_{2} \mathrm{O}_{3}, \mathrm{Sc}_{2} \mathrm{O}_{3}, \mathrm{Sm}_{2} \mathrm{O}_{3}$ and $\mathrm{Yb}_{2} \mathrm{O}_{3}$ (Table 2). They exhibit high solubility in the zirconia fluorite structure. Among these, the most frequently used is $\mathrm{Y}_{2} \mathrm{O}_{3}$ followed by $\mathrm{Sc}_{2} \mathrm{O}_{3}$.

The conductivity of doped zirconia depends on the dopant concentration. Several studies show that the conductivity of zirconia increases with adding $\mathrm{Y}_{2} \mathrm{O}_{3}$ until $8 \mathrm{~mol} \%$ and then decreases for higher yttria additions. $\left(\mathrm{Y}_{2} \mathrm{O}_{3}\right)_{0.08}\left(\mathrm{ZrO}_{2}\right)_{0.92}$ is widely employed as an electrolyte material in high temperature SOFCs because of its sufficient ionic conductivity and stability in both oxidizing and reducing environments. Beyond that, its components are abundant, inexpensive and it is easy to produce (Tarancón, 2009). Yttria doped zirconia (YSZ) is also stable in contact with a lot of electrode materials below $1100^{\circ} \mathrm{C}$. Unfortunately, La and $\mathrm{Sr}$ containing cathodes, react with YSZ at higher temperature producing insulating phases such as $\mathrm{La}_{2} \mathrm{Zr}_{2} \mathrm{O}_{7}$ and $\mathrm{SrZrO}_{3}$ at the cathode-electrolyte interface. It blocks the ion migration (EG\&G Technical services, 2000; Brant, 2006).

Scandia doped zirconia (ScSZ) has drawn attention for its utilization as electrolyte because of its high ionic conductivity (Table 2). However, at high temperature, ScSZ suffers thermal aging, reducing its conductivity. Its high ionic conductivity might enable the use of ScSZ at 
intermediate temperatures, in which there is no significant degradation. The main limiting factors in this case are the purity and availability of scandium oxide (Kharton et al., 2004).

\begin{tabular}{|c|c|c|c|}
\hline Dopant & Content $(\% \mathrm{~mol})$ & $\sigma_{\mathrm{i}}$ at $1000{ }^{\circ} \mathrm{C}\left(\mathrm{S} . \mathrm{cm}^{-1}\right)$ & Activation energy $\left(\mathrm{kJ} \cdot \mathrm{mol}^{-1}\right)^{*}$ \\
\hline $\mathrm{Y}_{2} \mathrm{O}_{3}$ & 8 & 10.0 & 96 \\
\hline $\mathrm{Sm}_{2} \mathrm{O}_{3}$ & 10 & 5.8 & 92 \\
\hline $\mathrm{Yb}_{2} \mathrm{O}_{3}$ & 10 & 11.0 & 82 \\
\hline $\mathrm{Sc}_{2} \mathrm{O}_{3}$ & 10 & 25.0 & 62 \\
\hline
\end{tabular}

*96.488 kJ.mol ${ }^{-1}=1 \mathrm{eV}$

Table 2. Values of ionic conductivity and activation energy of zirconia stabilized with different cations (adapted from Florio et al., 2004)*

The characteristics of the electrolyte, mainly its ionic conductivity and thickness, determine the operating temperature range of the SOFC. YSZ electrolyte cells operate satisfactorily only at temperatures above $850{ }^{\circ} \mathrm{C}$. . Doped $\mathrm{CeO}_{2}$ and doped $\mathrm{LaGaO}_{3}$ have shown promise for the replacement of YSZ in intermediate temperature SOFCs $\left(600-800{ }^{\circ} \mathrm{C}\right)$ (IT-SOFC) due to their higher conductivity. Other new materials for use in IT-SOFC are salt-oxide composite materials and NANOCOFC materials (nanocomposites for advanced fuel cell technology) (Nesaraj, 2010; Raza et al., 2010).

When compared to stabilized zirconia, doped ceria presents ionic conductivities approximately one order of magnitude greater, for similar temperature conditions. This is due to the larger ionic radius of $\mathrm{Ce}^{4+}(0.87 \AA)$ as compared to $\mathrm{Zr}^{4+}(0.72 \AA)$ producing a more open structure through which oxide ions can easily conduct (Faro et al., 2009).

Unlike zirconia, ceria naturally presents a fluorite structure since room temperature up to its melting point at $2400{ }^{\circ} \mathrm{C}$. So, in its case the only function of the doping is an increase of the ionic conductivity through the formation of vacancies. The main doping cations used for ceria are $\mathrm{Gd}^{3+}, \mathrm{Sm}^{3+}$ and $\mathrm{Y}^{3+}$. Among them, $\mathrm{Gd}^{3+}$ is the most commonly used. The ions $\mathrm{Gd}^{3+}$ and $\mathrm{Ce}^{4+}$ have the lowest ionic radius mismatch, so in the case of $\mathrm{Gd}$ doping the lattice presents the smallest internal stress and consequently the lowest activation energy for the $\mathrm{O}^{2-}$ conduction (Fergus et al., 2009). The $\mathrm{Ce}_{0.9} \mathrm{Gd}_{0.1} \mathrm{O}_{1.95}$ composition is promising for ITSOFC applications because of its high ionic conductivity at $500{ }^{\circ} \mathrm{C}$ ( Table 3 ).

\begin{tabular}{|c|c|c|c|c|}
\hline Composition & Dopant & $\begin{array}{c}\sigma_{\mathrm{i}} 500^{\circ} \mathrm{C} \\
\left({\left.\mathrm{S} . \mathrm{cm}^{-1}\right)}^{-1}\right.\end{array}$ & $\begin{array}{c}\sigma_{\mathrm{i}} 600^{\circ} \mathrm{C} \\
\left({\left.\mathrm{S} . \mathrm{cm}^{-1}\right)}^{-}\right.\end{array}$ & $\begin{array}{c}\sigma_{\mathrm{i}} 700^{\circ} \mathrm{C} \\
\left({\left.\mathrm{S} . \mathrm{cm}^{-1}\right)}^{-1}\right.\end{array}$ \\
\hline $\mathrm{Ce}_{0.9} \mathrm{Gd}_{0.1} \mathrm{O}_{1.95}$ & $\mathrm{Gd}^{3+}$ & 0.0095 & 0.0253 & 0.0544 \\
\hline $\mathrm{Ce}_{0.9} \mathrm{Sm}_{0.1} \mathrm{O}_{1.95}$ & $\mathrm{Sm}^{3+}$ & 0.0033 & 0.0090 & 0.0200 \\
\hline $\mathrm{Ce}_{0.887} \mathrm{Y}_{0.113} \mathrm{O}_{1.9435}$ & $\mathrm{Y}^{3+}$ & 0.0087 & 0.0344 & 0.1015 \\
\hline $\mathrm{Ce}_{0.8} \mathrm{Gd}_{0.2} \mathrm{O}_{1.9}$ & $\mathrm{Gd}^{3+}$ & 0.0053 & 0.0180 & 0.0470 \\
\hline
\end{tabular}

Table 3. Ionic conductivities of the means dopants of ceria at different temperatures (Adapted from Steele, 2000) 
Beside its high ionic conductivity, gadolinium doped ceria (GDC) also is compatible with the use of LSCF cathodes, since the chemical reaction between these materials is negligible. Their TEC values are also fairly similar (Dutta et al., 2009). However, $\mathrm{Ce}^{4+}$ reduces to $\mathrm{Ce}^{3+}$ under the reducing anode atmosphere at elevated temperatures. This induces an electronic conductivity (and phase changes) which decreases the open circuit voltage and increases the fuel consumption, consequently reducing the cell performance (Nesaraj, 2010; Steele, 2000). To avoid the $\mathrm{Ce}^{4+}$ reduction, it is common to insert an YSZ thin film between the ceria electrolyte and the anode (Dutta et al., 2009; Tietz et al., 2006). At temperatures lower than $500{ }^{\circ} \mathrm{C}$ the electronic conductivity is smaller and it has been suggested that this could be an optimal operating temperature range for the fuel cells based on ceria (Kharton et al, 2004).

\subsubsection{Doped lanthanum gallate}

Oxygen conductors with perovskite cubic structure based on lanthanum gallate $\mathrm{LaGaO}_{3}$ have also been investigated as SOFC electrolytes. In these ceramics, La can be partially replaced by $\mathrm{Sr}, \mathrm{Ca}, \mathrm{Ba}, \mathrm{Sm}$ and $\mathrm{Nd}$, while $\mathrm{Ga}$ may also be partially replaced by $\mathrm{Mg}$, In, $\mathrm{Al}$ or $\mathrm{Zn}$, as in $\mathrm{La}_{1-\mathrm{x}} \mathrm{Sr}_{\mathrm{x}} \mathrm{Ga}_{1-\mathrm{y}} \mathrm{Mg}_{\mathrm{y}} \mathrm{O}_{3-\delta}$ (LSGM). Compositions containing $\mathrm{Sr}$ and $\mathrm{Mg}$ substitutions respectively for La (between 10 and 20\%) and Ga (between 10 and 20\%) showed high ionic conductivities in both oxidizing and reducing atmosphere. Their TEC are comparable to the other usual cell components. The higher ionic conductivity was found for the $\mathrm{La}_{0.8} \mathrm{Sr}_{0.2} \mathrm{Ga}_{0.83} \mathrm{Mg}_{0.17} \mathrm{O}_{3-\delta}$ composition. It reaches about $0.17 \mathrm{~S} . \mathrm{cm}^{-1}$ at $800{ }^{\circ} \mathrm{C}$ (Badwal, 2001). However, these ceramics are unstable under reducing atmospheres and Ga losses are observed, resulting in the formation of new phases (Kharton et al., 2004; Wincewicz \& Cooper, 2004). These facts decrease the use of doped lanthanum gallate as SOFC electrolyte.

\begin{tabular}{|c|c|c|}
\hline Composition & $\mathrm{\sigma}_{\mathrm{i}}$ at $800{ }^{\circ} \mathrm{C}\left(\mathrm{S} . \mathrm{cm}^{-1}\right)$ & TEC $\left(\times 10^{-6} \mathrm{~K}^{-1}\right)$ \\
\hline$\left(\mathrm{Y}_{2} \mathrm{O}_{3}\right)_{0.08}\left(\mathrm{ZrO}_{2}\right)_{0.92}$ & 10.5 & 0.03 \\
\hline$\left(\mathrm{Sc}_{2} \mathrm{O}_{3}\right)_{0.08}\left(\mathrm{ZrO}_{2}\right)_{0.92}$ & 10.7 & 0.13 \\
\hline $\mathrm{Ce}_{0.8} \mathrm{Gd}_{0.2} \mathrm{O}_{1.9}$ & 12.5 & 0.053 \\
\hline $\mathrm{Ce}_{0.8} \mathrm{Sm}_{0.2} \mathrm{O}_{1.9}$ & 12.2 & 0.095 \\
\hline $\mathrm{La}_{0.9} \mathrm{Sr}_{0.1} \mathrm{Ga}_{0.8} \mathrm{Mg}_{0.2} \mathrm{O}_{2.85}$ & 10.7 & 0.1 \\
\hline
\end{tabular}

Table 4. Ionic conductivity and TEC of electrolyte materials in air at $800{ }^{\circ} \mathrm{C}$ (Adapted from Sun et al., 2010)*

\subsection{Anode}

The anode provides reaction sites for the electrochemical oxidation of the fuel gas. An adequate anode has: (1) high electrical conductivity; (2) a TEC that matches those of the adjoining components; (3) the capacity of avoid coke deposition; (4) fine particle size; (5) chemical compatibility with another cell components (electrolyte and interconector) under a reducing atmosphere at the operating temperature; (6) large TPB; (7) high electrochemical or catalytic activity for the oxidation of the selected fuel gas; (8) high porosity (20 - $40 \%$ ) adequate for the fuel supply and the reaction product removal; (9) good electronic and ionic conductive phases (Florio et al., 2004; Singhal .\& Kendall, 2003). 
$\mathrm{Ni}$ /YSZ cermet (YSZ: yttria stabilized zirconia) is the most common anode material in the SOFC which implement hydrogen as a fuel. The raisons for this choice are its low cost, its chemical stability and its TEC closed to that of the YSZ electrolyte. The high catalytical activity of $\mathrm{Ni}$ for the $\mathrm{H}-\mathrm{H}$ bond breaking and its relatively low cost justify the use of $\mathrm{Ni}$. Other catalytic components including $\mathrm{Cu}, \mathrm{Co}$ and phosphorous composites are being investigated, but they need further improvements before they can be effectively used (Florio et al., 2007; Martins et al., 2009; Sun et al., 2007).

The Ni particles coalescence is the main cause of the anode degradation. The YSZ grains constitute a framework which acts as an inhibitor for the coarsening of the Ni powders during cell operation. The TEC of nickel $\left(16.9 \times 10^{-6} \mathrm{~K}^{-1}\right)$ is much larger than that of YSZ $\left(11.0 \times 10^{-6} \mathrm{~K}^{-1}\right)$; the use of YSZ as a composite component also makes the TEC of the composite closer to those of other SOFC components. Furthermore, it improves the ionic conductivity of the material (Badwal, et al., 2001; Florio et al., 2004).

The Ni to YSZ volume ratio usually varies from 35:65 to 55:45. This ratio influences in the conductivity of the material. It may vary by several orders of magnitude $(\sim 0.1 \mathrm{~S} / \mathrm{cm}$ to the range of $\sim 10^{3} \mathrm{~S} / \mathrm{cm}$ ) because of the electrical conductivity of Ni which is more than 5 orders of magnitude greater than that of YSZ under the fuel cell operating conditions. The choice of an adequate composite composition is determining.

The cermet conductivity occurs through two mechanisms: ionic (through the YSZ phase) and electronic (through the metallic nickel phase). For Ni concentrations below $30 \%$ in volume, the conductivity is predominantly ionic. Above $30 \%$ in volume, it is predominantly electronic (typical of metals). The electrical conductivity of the Ni/YSZ cermet attains its maximum at $\mathrm{Ni}$ percolation estimated to be at approximately $30 \%$ in volume (Amado et al., 2007; Badwal, et al., 2001; Florio et al., 2004). The internal resistance (the resistance to the transport of electrons within the anode), contact resistance (caused by poor adherence between anode and electrolyte), concentration polarization resistance (related to the transport of the gaseous species through the electrodes) and activation polarization resistance (associated to the charge transfer processes) influence strongly the ASR of the anode. The anode performance is also largely depending on its thickness, its microstructure (grain size distribution, grain morphology, connectivity of $\mathrm{Ni}$ particles, porosity,) and number of TPBs (Sun et al., 2007).

Through these parameters, the anode performance is also influenced by the sintering temperature and the initial Ni and YSZ particle sizes. A fitting contact between Ni and YSZ particles decreases both the anode bulk and interfacial resistances. A high sintering temperatures $\left(\sim 1350-1400{ }^{\circ} \mathrm{C}\right)$ provides better anode performance and electrolyte interfacial contact and limits Ni coarsening (Bao et al., 2005; Singhal \& Kendall, 2003).

Anode films are employed as cell support with different thicknesses depending on the SOFC cell design. In the planar designs, the thickness is about $1-3 \mathrm{~mm}$.

For SOFC intended to use ethanol, methanol and gasoline or natural gas as fuels, the $\mathrm{Ni}$ /YSZ composite is not a good choice, because of its low tolerance to sulfur and carbon deposition. This problem can be avoided by reducing the operating temperature or by the development of alternative anode materials.

$\mathrm{Cu}$-anodes based on $\mathrm{Cu} / \mathrm{Ni}$ alloys have been used but $\mathrm{Cu}$ is not as good an electrocatalyst as $\mathrm{Ni}$ and with the YSZ electrolyte the power density is lower than with the Ni anodes. To increase the activity and stability of the Cu-based anodes, $\mathrm{Cu}$ can be alloyed with a second metal, for this purpose, nickel seems to be a good choice (Sun et al., 2007). Various metallic 
alloys as components of the cermets such as (Cu, Co, Fe) Ni-YSZ; (Ni,Co)-YSZ; (Ni,Fe)-YSZ; $(\mathrm{Ni}, \mathrm{Cu})-\mathrm{YSZ}$ and $(\mathrm{Cu}, \mathrm{Co})-\mathrm{YSZ}$ have been used for the direct oxidation of $\mathrm{CH}_{4}$ (Benyoucef et al., 2008; Ringuede et al., 2001).

Alternative materials which exhibit mixed ionic and electronic conductivity have been investigated as potential SOFC anodes capable of reforming hydrocarbons. Ceramics based on $\mathrm{CeO}_{2}$ are good examples of mixed conduction materials under a reducing atmosphere, (due to the partial reduction of $\mathrm{Ce}^{4+}$ into $\mathrm{Ce}^{3+}$.) These ceramics have an excellent catalytic activity for the hydrocarbon reforming reactions and they are resistant to carbon deposition. This allows for a direct supply of dry hydrocarbon fuels to the anode (Ramirez-Cabrera et al., 2000 as cited in Sun et al, 2007). The efficient catalytic activity of $\mathrm{CeO}_{2}$ based materials has been emphasized by Sun et al., 2006 as cited in Sun et al., 2007. The addition of Ni, Co or a noble metal such as $\mathrm{Pt}, \mathrm{Rh}, \mathrm{Pd}$ or $\mathrm{Ru}$ which easily breaks the $\mathrm{C}-\mathrm{H}$ bonds (Fergus et al., 2009; Sun et al., 2007) in the hydrocarbons is a further improvement. For example, Ru-NiGDC anodes used in a Ceria-based SOFC showed good results, with various hydrocarbons according to Hibino et al., 2003 (see Table 6 for the materials performance).

New materials with the cubic perovskite structure have also been suggested as alternative anode materials. The perovskite structure with general formula $\mathrm{ABO}_{3}$ where $\mathrm{A}$ are cations such as, $\mathrm{La}, \mathrm{Sr}, \mathrm{Ca}$ and $\mathrm{Pb}$, etc and $\mathrm{B}$ cations such as $\mathrm{Ti}, \mathrm{Cr}, \mathrm{Ni}, \mathrm{Fe}, \mathrm{Co}$ and $\mathrm{Zr}$ exhibit a very broad range of physical properties.

A $\mathrm{La}_{0.6} \mathrm{Sr}_{0.4} \mathrm{Fe}_{0.8} \mathrm{Co}_{0.2} \mathrm{O}_{3-\delta}-\mathrm{Ce}_{0.8} \mathrm{Gd}_{0.2} \mathrm{O}_{1.9}$ (LSFCO-GDC) composite anode materials and $\mathrm{La}_{0.75} \mathrm{Sr}_{0.25} \mathrm{Cr}_{0.5} \mathrm{Mn}_{0.5} \mathrm{O}_{3-\delta}$ (LSCM) were investigated and are efficient anode electro-catalysts (Huang et al., 2009; Morales et al., 2006; Sin et al., 2005; Sun et al, 2007). These materials showed good performance and stability in methane-fed SOFC in absence of Ni or noble metal catalysts. These anodes can be used withYSZ or GDC electrolytes. They are resistant to carbon deposition. Some examples of cell performance and operating conditions are given in Table 6 .

Another perovskite, A-site deficient, is the La-doped $\mathrm{SrTiO}_{3}$ (LST). It has been evaluated as a potential anode component for IT-SOFCs due to its thermal and chemical compatibilities with the electrolyte material to its sulfur tolerance. Some researchers have reported a sulfur poisoning by $\mathrm{H}_{2} \mathrm{~S}$ in the range of 26 to $1000 \mathrm{ppm}$, others have reported no poisoning effect in 1000 ppm $\mathrm{H}_{2} \mathrm{~S}$ and an enhancement effect in 5000 ppm. (Savaniu \& Irvine, 2010; Yoo \& Choi, 2010).

La-doped $\mathrm{SrTiO}_{3}\left(\mathrm{La}_{0.2} \mathrm{Sr}_{0.8} \mathrm{TiO}_{3}\right)$ is a candidate as an anode material to solve the problem of Ni-based anode in $\mathrm{LaGaO}_{3}$-based SOFC according to Yoo \& Choi (Yoo \& Choi, 2010). Some details of their tests are showed in Table 6. The addition of GDC into LST reduces the anode polarization, leading to an increased performance.

The cell performance with $\mathrm{Ni}$ based anodes decreases quickly by sulfur poisoning which generally becomes more severe as the temperature decreases or as the $p \mathrm{H}_{2} \mathrm{~S} / p \mathrm{H}_{2}$ increases (Fergus, et al., 2009; Sun et al., 2007). Matsuzaki et al., 2007 showed that SOFCs which utilize $\mathrm{Ni}-\mathrm{YSZ}$ cermet anodes are susceptible to poisoning by sulfur contents as low as $2 \mathrm{ppm} \mathrm{H}_{2} \mathrm{~S}$ at $1273 \mathrm{~K}$. In their work it was observed that the performance loss is reversible at $\mathrm{H}_{2} \mathrm{~S}$ concentrations less than $15 \mathrm{ppm}$.

\section{Manufacturing ceramic films}

SOFC thin films are prepared by slurry or suspension depositions. The suspensions are constituted of ceramic powders, dispersants, binders, solvents and plasticizers. Only stabilised precursor suspensions must be used to avoid the formation of any agglomerates 
which would affect negatively the final quality of the films. The flocculation and sedimentation are frequent situations observed during the preparation of slurries. The formation of flocculates occurs due to the van der Waals attractive forces between the particles. When the oxide particles are placed in a liquid medium an electrical double layer is formed around them with one layer composed of ions tightly adsorbed on the surface of the particles (Stern layer). The other layer is composed of ions less firmly adsorbed (diffuse layer), as showed in Fig. 7. This results in a potential profile between the particle surface and the bulk of the dispersing liquid. The last part of the potential difference is called the zeta potential and it is measured at the slipping plane (boundary of the diffuse layer). The zetapotential is a measurement of the amount of charge present on the particle surface relative to the bulk of the dispersing media (Ramanathan et al., 2005).

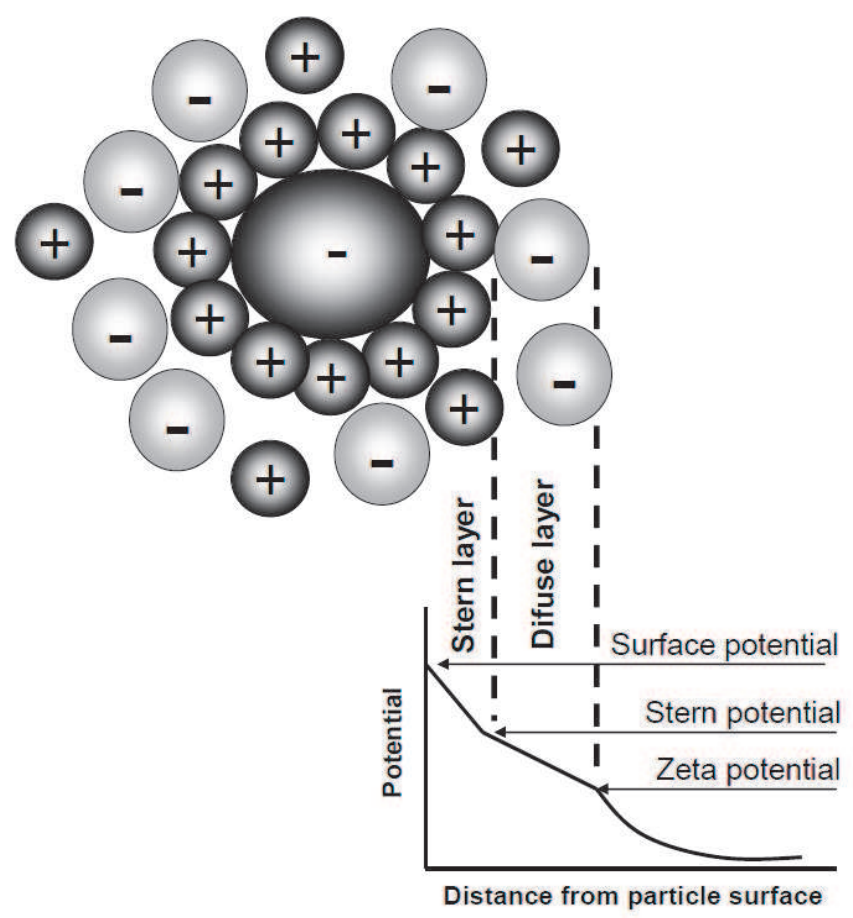

Fig. 7. Schematic representation of zeta potential.

The zeta potential depends on the suspension $\mathrm{pH}$ and measures indirectly the magnitude of repulsive forces necessary to prevent the formation of flocculates. The higher the zeta potential, the more predominant is the electrostatic repulsion between the electric double layers, resulting in a lower agglomeration and a lower viscosity value. The zero value of the zeta potential, the isoelectric point, indicates the $\mathrm{pH}$ at which the particles tend to form flocculates. It is important that the suspensions are prepared in $\mathrm{pH}$ giving the maximum zeta potential (in module) (Fonseca et al., 2009; Maiti \& Rajende, 2002; Ramanathan et al., 2005). 
Parameters such as the slurry composition and preparation and the grain size of the powders affect the particle surface charge and on the Zeta potential (Fonseca et al., 2009; Maiti \& Rajende,2002).

The stabilisation mechanisms of the suspension are caused by both, steric hindrance and steric stabilisation. Organic components such as dispersants, binders and plasticisers which are added to the suspension contribute to the stabilisation, making the repulsive forces between the electric double layers larger than the attractive forces. The dispersant keeps the ceramic particles in a stable suspension in the slurry (Maiti \& Rajende, 2002). It permits the particles to settle into a densely packed green tape when the solvent evaporates. So an effective dispersant can increase the quality of the green films. Maiti \& Rajende, 2002 showed, that terpineol is an effective dispersant in the preparation of green ceramic tape of yttria stabilized zirconia. It has higher density both in green and fired stages, higher flexibility of green tapes that the conventional dispersants such as menhaden fish oil (MFO) and phosphate ester (PE). Accordingly, rheological measurements made by Maiti and Rajender, 2002 showed that the lowest viscosity of a 50 g powder suspension was obtained with $0.39 \mathrm{~mL}$ of phosphate ester, $2 \mathrm{~mL}$ of fish oil and $1.5 \mathrm{~mL}$ of terpineol.

Tseng \& Chen, 2003 studied the effect of polymeric dispersants on the rheological behavior of nickel suspensions in a terpineol solvent. The rheological behavior was investigated according to the dispersant type, dispersant concentration ( $0.5-10 \%$ of the powder weight) and solids loading (3-10 vol.\%) over a shear-rate range of $1-1,000 \mathrm{~s}^{-1}$. The suspensions exhibited pseudoplastic behavior, revealing that the mixtures were flocculated in structure. The suspension viscosity showed a minimum when the dispersant concentration exceeds 2 wt. \% of the solids. For this dispersant concentration the viscosity was about $60 \%$ of the sample without dispersant.

Mukherje et al., 2001 studied the role of the dispersant (MFO and PE) and the YSZ powder dimensions on the slurry rheology and the effect on green as well as sintered densities of tape cast YSZ. Their results showed that the MFO was more effective than PE and the best dispersion was obtained with finer particle.

Fonseca et al., 2009 fabricated NiO/YSZ anode functional layer with 40 wt.\% of NiO. The slurries were prepared by two concentrations of polymethylmethacrylate (PMMA): 1 and 2 wt.\%. The slurries presented pseudoplastic and thixotropic behaviors. The suspension with 2 wt.\% PMMA was more homogeneous, and maintained chemical stability over a longer period of time. It was adequate for the SOFC anode functional layer preparation.

Suspensions with flocculates are known to have shear-thinning behaviour (pseudoplastic behaviour), usually with a higher viscosity that decreases with the rate of shear. The flocculates present in slurries trap water inside their structure, thereby making it unavailable for flow and thus increasing the slurry viscosity. Upon shearing, the flocculates break and the water become available for flow, thereby decreasing the slurry's viscosity (Fonseca et al., 2009; Nascimento et al., 2009; Ramanathan et al., 2005). It is important to determine how zeta potential and rheology measurements are correlated with the stability of slurries.

The choice of the deposition method (Table 5) essentially depends on the type of selected cell configuration, desired characteristics of the films, cost, potential for automation and reproducibility. 


\begin{tabular}{|c|c|c|c|}
\hline Deposition Technique & Brief Description & $\begin{array}{l}\begin{array}{l}\text { Common } \\
\text { application }\end{array} \\
\end{array}$ & Features \\
\hline $\begin{array}{l}\text { Screen printing } \\
\text { (Tiez et al., 2002; } \\
\text { Fergus et al., 2009; Lu } \\
\text { et al., 2010; Singhal \& } \\
\text { Kendall, 2001) }\end{array}$ & $\begin{array}{l}\text { The suspension to be } \\
\text { deposited is placed on a } \\
\text { screen and its passage is } \\
\text { forced by pressure. }\end{array}$ & $\begin{array}{l}\text { Cathode, anode } \\
\text { and electrolyte }\end{array}$ & $\begin{array}{l}\text { Scale-up is easily } \\
\text { feasible. Insufficient } \\
\text { densification and } \\
\text { cracking of some ceria } \\
\text { based electrolytes. }\end{array}$ \\
\hline $\begin{array}{l}\text { Tape casting } \\
\text { (Tiez et al., 2002; } \\
\text { Fergus et al., 2009; } \\
\text { EG\&G Technical } \\
\text { services, 2000; Singhal } \\
\text { \& Kendall, 2001) }\end{array}$ & $\begin{array}{l}\text { The ceramic film is } \\
\text { deposited on a } \\
\text { temporary support, } \\
\text { which consists of a } \\
\text { mobile sheet. The } \\
\text { desired thickness is } \\
\text { obtained by a doctor } \\
\text { blade device. }\end{array}$ & $\begin{array}{l}\text { Anode and } \\
\text { electrolyte }\end{array}$ & $\begin{array}{l}\text { Scale-up is easily } \\
\text { feasible, production of } \\
\text { multilayer cells, able } \\
\text { to product electrolyte } \\
\text { with various } \\
\text { thicknesses. } \\
\text { Inappropriate for } \\
\text { large cell areas. }\end{array}$ \\
\hline $\begin{array}{l}\text { Atmospheric Plasma } \\
\text { spray (APS) } \\
\text { (Fergus et al., 2009, } \\
\text { Singhal \& Kendall, } \\
2001 \text { ) }\end{array}$ & $\begin{array}{l}\text { The method uses a } \\
\text { plasma jet }(\sim 10,000 \mathrm{~K}) \text { to } \\
\text { melt particles which are } \\
\text { sprayed on a substrate } \\
\text { with fast solidification. }\end{array}$ & $\begin{array}{l}\text { Cathode, anode, } \\
\text { electrolyte and } \\
\text { interconnector }\end{array}$ & $\begin{array}{l}\text { Fast deposition, } \\
\text { achievement of films } \\
\text { with different } \\
\text { compositions and } \\
\text { microstructure, } \\
\text { possibility of } \\
\text { depositing SOFC } \\
\text { layers on metallic } \\
\text { substrates without } \\
\text { subsequent sintering, } \\
\text { scale-up is easily } \\
\text { feasible. }\end{array}$ \\
\hline $\begin{array}{l}\text { Spray pyrolyse } \\
\text { (Fergus et al., 2009, } \\
\text { Singhal \& Kendall, } \\
\text { 2001; Perednis \& } \\
\text { Gauckler, 2004) }\end{array}$ & $\begin{array}{l}\text { The film is deposited } \\
\text { by spraying a } \\
\text { suspension containing } \\
\text { powder precursor } \\
\text { and/or the already } \\
\text { produced powder onto } \\
\text { a hot substrate } \\
\text { followed by sintering. }\end{array}$ & Electrolyte & $\begin{array}{l}\text { Thin and gas-tight } \\
\text { electrolytes, } \\
\text { possibility of } \\
\text { producing multiple } \\
\text { gradient layers by } \\
\text { changing the solution. }\end{array}$ \\
\hline $\begin{array}{l}\text { Colloidal spray } \\
\text { deposition (CSD) } \\
\text { (Fergus et al., 2009) }\end{array}$ & $\begin{array}{l}\text { A colloidal sol is } \\
\text { released through a } \\
\text { pump to a liquid } \\
\text { dispersing apparatus, } \\
\text { like an ultrasonic } \\
\text { nozzle onto a heated } \\
\text { substrate. }\end{array}$ & $\begin{array}{l}\text { Cathode and } \\
\text { electrolyte }\end{array}$ & $\begin{array}{l}\text { Low cathode ASR } \\
\text { (area specific } \\
\text { resistance), increasing } \\
\text { in power density. }\end{array}$ \\
\hline $\begin{array}{l}\text { Chemical vapor } \\
\text { deposition (CVD) } \\
\text { (Fergus et al., 2009; } \\
\text { Santillán et al., 2009) }\end{array}$ & $\begin{array}{l}\text { Deposition is done by } \\
\text { gas phase reaction } \\
\text { between metal halide } \\
\text { precursors and a heated } \\
\text { substrate. }\end{array}$ & $\begin{array}{l}\text { Cathode and } \\
\text { electrolyte }\end{array}$ & $\begin{array}{l}\text { Electrolyte thin film } \\
\text { Low deposition, high } \\
\text { temperatures } \\
\text { required, high } \\
\text { equipment costs, } \\
\text { corrosive products. }\end{array}$ \\
\hline
\end{tabular}




\begin{tabular}{|c|c|c|c|}
\hline Deposition Technique & Brief Description & $\begin{array}{l}\text { Common } \\
\text { application }\end{array}$ & Features \\
\hline $\begin{array}{l}\text { Electrochemical vapor } \\
\text { deposition (EVD) } \\
\text { (Fergus et al., 2009; } \\
\text { Singhal \& Kendall, } \\
\text { 2001) }\end{array}$ & $\begin{array}{l}\text { In a chamber at one side of } \\
\text { the substrate, is placed } \\
\text { metal chloride vapors and } \\
\text { at the other side it is placed } \\
\text { water vapor or oxygen. } \\
\text { First, there is the pore } \\
\text { closure of the substrate by } \\
\text { the reaction between the } \\
\text { metal chloride and water } \\
\text { vapor. After that, the } \\
\text { formation of an } \\
\text { electrochemical potential } \\
\text { gradient causes the film } \\
\text { growth. }\end{array}$ & $\begin{array}{l}\text { Electrolyte in } \\
\text { tubular cells and } \\
\text { interconnect }\end{array}$ & $\begin{array}{l}\text { Dense film deposition } \\
\text { on porous substrate; it } \\
\text { can be used on tubular } \\
\text { substrate, obtaining of } \\
\text { homogeneous films } \\
\text { with good mechanical } \\
\text { properties; do not } \\
\text { require high } \\
\text { temperature for } \\
\text { sintering. } \\
\text { Increase SOFC's cost, } \\
\text { high temperature } \\
\text { required for fast } \\
\text { deposition. }\end{array}$ \\
\hline $\begin{array}{l}\text { Spin coating } \\
\text { (Fergus et al., 2009, } \\
\text { EG\&G Technical } \\
\text { services, 2000; Singhal } \\
\text { \& Kendall, 2001) }\end{array}$ & $\begin{array}{l}\text { A sol gel precursor is } \\
\text { spun on a dense or } \\
\text { porous substrate to } \\
\text { produce a film which } \\
\text { thickness is controlled by } \\
\text { the stir rate. }\end{array}$ & Electrolyte & $\begin{array}{l}\text { Thin and dense } \\
\text { electrolyte }\end{array}$ \\
\hline $\begin{array}{l}\text { Dip coating or Slurry } \\
\text { coating (Matsuda et } \\
\text { al., 2007; EG\&G } \\
\text { Technical services, } \\
\text { 2000; Fergus et al., } \\
\text { 2009; Santillán et al., } \\
\text { 2009; Singhal \& } \\
\text { Kendall, 2001) }\end{array}$ & $\begin{array}{l}\text { The substrate is } \\
\text { submerged in an aqueous } \\
\text { or alcoholic suspension. } \\
\text { After that, the film is dried } \\
\text { at room temperature, } \\
\text { preheated and following } \\
\text { sintered. This process is } \\
\text { repeated several times. }\end{array}$ & $\begin{array}{l}\text { Cathode, anode } \\
\text { and electrolyte }\end{array}$ & $\begin{array}{l}\text { Low cost. } \\
\text { Time consuming. }\end{array}$ \\
\hline $\begin{array}{l}\text { Tape calendaring } \\
\text { (Fergus et al., 2009; } \\
\text { EG\&G Technical } \\
\text { services, 2000; Singhal } \\
\text { \& Kendall, 2001) }\end{array}$ & $\begin{array}{l}\text { Similar to tape casting, } \\
\text { but the film thickness is } \\
\text { controlled by the spacing } \\
\text { between rollers. The } \\
\text { deposited suspension is } \\
\text { a thermoplastic material. }\end{array}$ & $\begin{array}{l}\text { Electrolyte and } \\
\text { anode }\end{array}$ & $\begin{array}{l}\text { Able to product } \\
\text { electrolyte with } \\
\text { various thicknesses, } \\
\text { production of } \\
\text { multilayer cells. }\end{array}$ \\
\hline $\begin{array}{l}\text { Sputtering } \\
\text { (Fergus et al., 2009; } \\
\text { Singhal \& Kendall, } \\
\text { 2001) }\end{array}$ & $\begin{array}{l}\text { A target material is } \\
\text { bombed with noble gas } \\
\text { ions, commonly argon } \\
\text { ions. Then, atoms or ions } \\
\text { of the target are released } \\
\text { and deposited on the } \\
\text { substrate. }\end{array}$ & $\begin{array}{l}\text { Cathode, anode } \\
\text { and electrolyte }\end{array}$ & $\begin{array}{l}\text { Obtaining of thin films } \\
\text { of electrolyte; control } \\
\text { of composition and } \\
\text { morphology; relatively } \\
\text { low temperature of } \\
\text { deposition. } \\
\text { Cracking of ceria films; } \\
\text { high cost; some } \\
\text { techniques, like radio- } \\
\text { frequency (RF) } \\
\text { sputtering and direct } \\
\text { current (DC) } \\
\text { sputtering can be slow. }\end{array}$ \\
\hline
\end{tabular}




\begin{tabular}{|c|c|c|c|}
\hline Deposition Technique & Brief Description & \begin{tabular}{|l|} 
Common \\
application
\end{tabular} & Features \\
\hline $\begin{array}{l}\text { Electrophoretic } \\
\text { deposition (EPD) } \\
\text { (Matsuda et al., 2007; } \\
\text { EG\&G Technical } \\
\text { services, 2000; } \\
\text { Santillán et al., 2009; } \\
\text { Fergus et al., 2009; } \\
\text { Singhal \& Kendall, } \\
\text { 2001) }\end{array}$ & $\begin{array}{l}\text { An electric field is } \\
\text { applied forcing charged } \\
\text { particles suspended in a } \\
\text { liquid to move toward } \\
\text { an electrode with } \\
\text { opposite charge. }\end{array}$ & $\begin{array}{l}\text { Cathode and } \\
\text { electrolyte }\end{array}$ & $\begin{array}{l}\text { Simple operation; } \\
\text { short time consuming; } \\
\text { uniform films, easy } \\
\text { deposition on } \\
\text { substrates with } \\
\text { complex forms; film } \\
\text { thickness control, } \\
\text { scale-up is easily } \\
\text { feasible; it is a cheaper } \\
\text { option for electrolyte } \\
\text { deposition onto } \\
\text { tubular cathode. }\end{array}$ \\
\hline $\begin{array}{l}\text { Pulsed-laser } \\
\text { deposition (PLD) or } \\
\text { laser ablation) (Fergus } \\
\text { et al., 2009) }\end{array}$ & $\begin{array}{l}\text { A material is removed } \\
\text { from a surface by laser at } \\
\text { vacuum and then } \\
\text { deposited on a substrate } \\
\text { at temperature about } 700 \\
{ }^{\circ} \mathrm{C} \text {. }\end{array}$ & $\begin{array}{l}\text { Cathode and } \\
\text { electrolyte }\end{array}$ & $\begin{array}{l}\text { Production of } \\
\text { miniaturized SOFC, } \\
\text { potential for } \\
\text { automation, obtaining } \\
\text { of nano-structures. }\end{array}$ \\
\hline $\begin{array}{l}\text { Sol Gel } \\
\text { (Fergus et al., 2009) }\end{array}$ & $\begin{array}{l}\text { The salts of the cations of } \\
\text { interest are dissolved } \\
\text { forming a sol system. The } \\
\text { colloid is then dried to } \\
\text { obtain a powder that is } \\
\text { deposited by conventional } \\
\text { methods or it is partially } \\
\text { dried to yield viscous } \\
\text { slurry that is deposited by } \\
\text { a wet method. }\end{array}$ & Electrolyte & $\begin{array}{l}\text { Do not require high } \\
\text { temperature for } \\
\text { sintering. }\end{array}$ \\
\hline $\begin{array}{l}\text { Painting } \\
\text { (Fergus et al., 2009) }\end{array}$ & $\begin{array}{l}\text { The suspension is } \\
\text { deposited by a paint } \\
\text { bush on the substrate. }\end{array}$ & $\begin{array}{l}\text { Electrodes and } \\
\text { electrolyte }\end{array}$ & $\begin{array}{l}\text { Simple method. } \\
\text { Difficult to scale up, } \\
\text { not reproducible. }\end{array}$ \\
\hline
\end{tabular}

Table 5. Some deposition techniques and their features*

\section{SOFC performance}

After optimizing the type of material of each component and the appropriate parameters for a stable suspension, the performance is evaluated by potential versus current density measurements. According Table 6 is possible to observe that the power density values can change according some parameters such as type anode, electrolyte and cathode, the fuel gas, the temperature and type of the cell configuration (electrolyte or electrode supported). The comparison between the power density values can be made only when tests are done under the same conditions. The operation of the cell at low temperatures is related to the significant decline in SOFCs performance. Solutions to improve the cell performance include the use of alternative components materials which has good performance in IT-SOFC, as discussed in previous sections, together with electrode supported cell which the power density is higher than electrolyte supported SOFC. 


\begin{tabular}{|c|c|c|c|c|c|c|}
\hline Ref & Anode & Cathode & Electrolyte & Fuel gas & $\begin{array}{c}\text { Maximum } \\
\text { power } \\
\text { density } \\
\left(\mathrm{mW}^{\left.-\mathrm{cm}^{-2}\right)}\right.\end{array}$ & $\begin{array}{l}\text { Tempe } \\
\text { rature } \\
\left({ }^{\circ} \mathrm{C}\right)\end{array}$ \\
\hline $\begin{array}{c}\text { Ding \& } \\
\text { Liu, } 2008\end{array}$ & $\begin{array}{l}\mathrm{NiO}-\mathrm{YSZ} \\
(0.5 \mathrm{~mm})\end{array}$ & $\mathrm{La}_{0.7} \mathrm{Sr}_{0.3} \mathrm{MnO}_{3} / \mathrm{YSZ}$ & $\begin{array}{c}\mathrm{ZrO}_{2} / \mathrm{Y}_{2} \mathrm{O}_{3} \\
14.9 \mu \mathrm{m}\end{array}$ & $\begin{array}{c}\mathrm{H}_{2} \\
\left(3 \text { wt. } \% \mathrm{H}_{2} \mathrm{O}\right)\end{array}$ & 990 & 800 \\
\hline $\begin{array}{l}\text { Murata et } \\
\text { al. } 2005\end{array}$ & $\begin{array}{c}\text { NiO-YSZ } \\
\text { (support cell) }\end{array}$ & $\mathrm{La}_{0.6 \mathrm{Sr}} \mathrm{Sr}_{.4} \mathrm{Co} 0.2 \mathrm{Fe}_{0.8} \mathrm{O}_{3-\mathrm{a}}$ & $\begin{array}{l}\mathrm{ZrO}_{2} / \mathrm{Y}_{2} \mathrm{O}_{3} \\
(0.2 \mathrm{~mm})\end{array}$ & $\begin{array}{c}\mathrm{H}_{2} \\
\left(3 \text { wt. } \% \mathrm{H}_{2} \mathrm{O}\right)\end{array}$ & 500 & 700 \\
\hline $\begin{array}{l}\text { Matsuda } \\
\text { et al., 2007 }\end{array}$ & $\begin{array}{c}\mathrm{NiO}-\mathrm{YSZ} \\
\text { (support cell) }\end{array}$ & $\begin{array}{c}\mathrm{La}_{0.6 .6} \mathrm{Sr}_{0.4} \mathrm{Co}_{0.2} \mathrm{Fe}_{0.8} \mathrm{O}_{3-\delta} \\
(30 \mu \mathrm{m}) .\end{array}$ & $\begin{array}{c}\mathrm{ZrO}_{2} / \mathrm{Y}_{2} \mathrm{O}_{3} \\
(4 \mu \mathrm{m})+ \\
\mathrm{SDC}(1 \mu \mathrm{m})\end{array}$ & $\begin{array}{c}\mathrm{H}_{2} \\
\left(3 \text { wt. } \% \mathrm{H}_{2} \mathrm{O}\right)\end{array}$ & 600 & 700 \\
\hline $\begin{array}{l}\text { Fan \& Liu, } \\
2009\end{array}$ & $\begin{array}{l}\mathrm{NiO}-\mathrm{YSZ} \\
0.8 \mathrm{~mm}\end{array}$ & $\begin{array}{c}\mathrm{La}_{0.54} \mathrm{Sr}_{0.44} \mathrm{Co}_{0.2} \mathrm{Fe}_{0.8} \mathrm{O}_{3-\delta} \\
6 \mu \mathrm{m}\end{array}$ & $\begin{array}{l}\mathrm{ZrO}_{2} / \mathrm{Y}_{2} \mathrm{O}_{3} \\
\quad 8 \mu \mathrm{m}\end{array}$ & $\mathrm{H}_{2}$ & 855 & 700 \\
\hline $\begin{array}{l}\text { Chen et, } \\
\text { al., } 2010\end{array}$ & $\begin{array}{c}\mathrm{NiO}-\mathrm{YSZ} \\
\text { (support cell) }\end{array}$ & $\begin{array}{c}\mathrm{La} 0.6 \mathrm{Sr}_{0.4} \mathrm{Co}_{0.2 \mathrm{2} \mathrm{Fe}_{0.8} \mathrm{O}_{3-\delta} /} / \mathrm{Y} \mathrm{O}_{3} / \mathrm{YSZ}_{2}\end{array}$ & $\begin{array}{c}\text { YSZ dense + } \\
\text { YSZ porous }(9 \\
\mu \mathrm{m})\end{array}$ & $\mathrm{H}_{2}$ & 473 & 750 \\
\hline $\begin{array}{l}\text { Liu \& } \\
\text { Barnett, } \\
2002\end{array}$ & $\begin{array}{l}\mathrm{NiO}-\mathrm{YSZ} \\
(0.5 \mathrm{~mm})\end{array}$ & $\begin{array}{c}\mathrm{La}_{0.6} \mathrm{Sr}_{0.4} \mathrm{Co}_{0.2} \mathrm{Fe}_{0.8} \mathrm{O}_{3-\delta} / \\
\quad \mathrm{Ce}_{0.9} \mathrm{Gd}_{0.1} \mathrm{O}_{1.95}\end{array}$ & $\begin{array}{c}\mathrm{ZrO}_{2} / \mathrm{Y}_{2} \mathrm{O}_{3} \\
25 \mu \mathrm{m}\end{array}$ & $\begin{array}{c}\mathrm{H}_{2} \\
\left(3 \text { wt. } \% \mathrm{H}_{2} \mathrm{O}\right)\end{array}$ & 930 & 800 \\
\hline $\begin{array}{l}\text { Tietz et al., } \\
2006\end{array}$ & $\begin{array}{l}\mathrm{NiO}-\mathrm{YSZ} \\
1.5 \mathrm{~mm}\end{array}$ & $\begin{array}{c}\mathrm{La}_{0.58} \mathrm{Sr}_{0.4} \mathrm{Co}_{0.2} \mathrm{Fe}_{0.8} \mathrm{O}_{3-\delta} \\
45 \mu \mathrm{m}\end{array}$ & $\begin{array}{c}\mathrm{ZrO}_{2} / \mathrm{Y}_{2} \mathrm{O}_{3} \\
\mathrm{Ce}_{0.8} \mathrm{Gd}_{0.2} \mathrm{O}_{2-\delta} \\
\text { interlayer }\end{array}$ & $\begin{array}{c}\mathrm{H}_{2} \\
\left.\text { (3wt. } \% \mathrm{H}_{2} \mathrm{O}\right)\end{array}$ & 1230 & 800 \\
\hline $\begin{array}{l}\text { Savaniu \& } \\
\text { Irvine, } \\
2010\end{array}$ & $\mathrm{La}_{0.2} \mathrm{Sr}_{0.7} \mathrm{TiO}_{3}$ & $\mathrm{La}_{0.6} \mathrm{Sr}_{0.4} \mathrm{CoO}_{3}$ & $\begin{array}{c}\mathrm{ZrO}_{2} / \mathrm{Y}_{2} \mathrm{O}_{3} \\
50-75 \mu \mathrm{m}\end{array}$ & $\begin{array}{c}\mathrm{H}_{2} \\
\left.\text { (3wt. } \% \mathrm{H}_{2} \mathrm{O}\right)\end{array}$ & 500 & 750 \\
\hline $\begin{array}{c}\text { Yoo \& } \\
\text { Choi, 2010 }\end{array}$ & $\begin{array}{l}\mathrm{La}_{0.2} \mathrm{Sr}_{0.8} \mathrm{TiO}_{3} \\
(\sim 15 \mu \mathrm{m})\end{array}$ & $\begin{array}{c}\mathrm{La}_{0.6} \mathrm{Sc}_{0.4} \mathrm{Co}_{0.2} \mathrm{Fe}_{0.8} \mathrm{O}_{3} \\
(\sim 15 \mu \mathrm{m})\end{array}$ & $\begin{array}{c}\mathrm{La} 0.9 \mathrm{Sr}_{0.1} \mathrm{Ga}_{0.8} \mathrm{M} \\
\mathrm{g}_{0.2} \mathrm{O}_{3} \\
(\sim 600 \mu \mathrm{m}- \\
\text { support cell })\end{array}$ & $\begin{array}{c}\mathrm{H}_{2} \\
\left(3 \text { wt. } \% \mathrm{H}_{2} \mathrm{O}\right)\end{array}$ & 300 & 800 \\
\hline $\begin{array}{l}\text { Liu et al., } \\
2007\end{array}$ & $\begin{array}{c}\mathrm{NiO} / \mathrm{GDC}: \\
\mathrm{NiO}- \\
\mathrm{Ce}_{0.9} \mathrm{Gd}_{0.1} \mathrm{O}_{1.95}\end{array}$ & $\begin{array}{c}\text { La } 0.6 \mathrm{Sr}_{0.4} \mathrm{Co}_{0.2} \\
\mathrm{Fe}_{0.8} \mathrm{O}_{3-\delta} / \mathrm{Ce}_{0.9} \mathrm{Gd}_{0.1} \mathrm{O}_{1.95} \\
\text { (2mm - support cell })\end{array}$ & $\begin{array}{c}\text { Ce } 0.9 \mathrm{Gd}_{0.1} \mathrm{O}_{1.95} \\
\text { (thickness: } \\
20 \mu \mathrm{m})\end{array}$ & $\begin{array}{c}\mathrm{H}_{2} \\
\left(3 \mathrm{wt} . \% \mathrm{H}_{2} \mathrm{O}\right)\end{array}$ & $\left|\begin{array}{c}35\left(550^{\circ} \mathrm{C}\right) \\
\text { and } \\
60\left(600^{\circ} \mathrm{C}\right)\end{array}\right|$ & $\begin{array}{l}550 \\
\text { and } \\
600\end{array}$ \\
\hline $\begin{array}{l}\text { Hibino et } \\
\text { al., } 2003\end{array}$ & 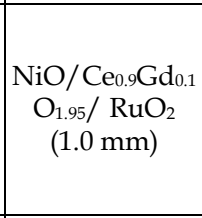 & $\mathrm{Sm}_{0.5} \mathrm{Sr}_{0.5} \mathrm{CoO}_{3}$ & $\begin{array}{c}\mathrm{Ce}_{0.9} \mathrm{Gd}_{0.1} \mathrm{O}_{1.95} \\
(25-40 \mu \mathrm{m})\end{array}$ & $\begin{array}{c}\text { Methane/ } \\
\text { Ethane/propa } \\
\text { ne }\end{array}$ & $\begin{array}{c}750 \\
\text { (methane), } \\
716 \\
\text { (ethane) } \\
648 \\
\text { (propane) }\end{array}$ & 600 \\
\hline $\begin{array}{l}\text { Sin et al., } \\
2005\end{array}$ & $\mid \begin{array}{c}\mathrm{La}_{0.6} \mathrm{Sr}_{0.4} \mathrm{Fe}_{0.8} \mathrm{Co} \\
0.2 \mathrm{O}_{3} / \mathrm{Ce}_{0.8} \mathrm{Gd}_{0.2} \\
\mathrm{O}_{1.9}\end{array}$ & 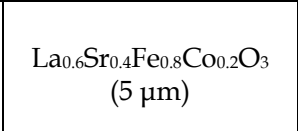 & $\begin{array}{c}\mathrm{Ce}_{0.8} \mathrm{Gd}_{0.2} \mathrm{O}_{1.9} \\
(300 \mu \mathrm{m}- \\
\text { support cell })\end{array}$ & Methane & 170 & 800 \\
\hline $\begin{array}{c}\text { Morales et } \\
\text { al., } 2006\end{array}$ & $\begin{array}{c}\mathrm{La} 0.75 \mathrm{Sr}_{0.25} \mathrm{Cr}_{0.5} \\
\mathrm{Mn}_{0.5} \mathrm{O}_{3-\delta}\end{array}$ & $\mathrm{La}_{0.75} \mathrm{Sr}_{0.25} \mathrm{Cr}_{0.5} \mathrm{Mn}_{0.5} \mathrm{O}_{3-\delta}$ & $\begin{array}{c}\mathrm{ZrO}_{2} / \mathrm{Y}_{2} \mathrm{O}_{3} \\
(1.6 \mathrm{~mm})\end{array}$ & $\begin{array}{c}\text { Hydrogen } / \text { me } \\
\text { thane }\end{array}$ & $\begin{array}{c}300\left(\mathrm{CH}_{4}\right) \\
\text { and } 500 \\
\left(\mathrm{H}_{2}\right)\end{array}$ & 950 \\
\hline
\end{tabular}

Table 6. Materials and electrical performance of SOFC according some authors* 
The configuration NiO-YSZ / YSZ / LSM-YSZ reported by Ding \& Liu, 2008 was intensively studied using hydrogen fuel. Later, there was a trend of substitution of LSM by LSCF because of its higher ionic and electronic conductivity. This material was studied by Murata et al. 2005, Matsuda et al. 2007 and Fan \& Liu, 2009 (Table 6). To further increase the ionic conductivity of LSCF, some researchers investigated the production of a composite of LSCF and an electrolyte material, as the work of Chen et al. 2010 and Liu \& Barnett, 2002. However, the reaction between LSCF and YSZ led many researchers to study the use of a protective layer of GDC between the LSCF and YSZ layers. In order to reduce the operating temperature of the cell, new materials for anode (as LST, studied by Savanna \& Irvine, 2010) and electrolyte (as LSGM studied by Yoo \& Choi, 2010 and CGD studied by Liu et al., 2007) were also tested. The latest research in terms of fuel cells seek to obtain high power densities through the use of fuels other than hydrogen, as studied by Hibino et al., 2003, Sin et al., 2005 and Morales et al., 2006.

\section{Conclusion}

SOFC technology offers a real alternative for relatively clean distributed power generation. Nowadays there is an intense search for materials and configurations of IT-SOFC cells with power densities as high as possible. For this intent new materials which have a long term stability with very low degradation are been tested such as perovskite-type oxides and fluorites. They are replacing conventional materials, especially in the SOFC operating with hydrocarbon. Besides the composition, the microstructure also needs further optimization. For this purpose, the preparation of stable suspensions and the choice of suitable deposition methods are crucial in order to improve electrochemical characteristics and the cost-effective fabrication of the cells. However for SOFCs commercialization, cost reduction is still a key issue.

\section{Acknowledgment}

The authors wish to thank CAPES (Coordenação de Aperfeiçoamento de Pessoal de Nível Superior); CNPq (Conselho Nacional de Desenvolvimento Científico e Tecnológico) CEMIG (Companhia Energética de Minas Gerais) and FAPEMIG (Fundação de Amparo a Pesquisa do Estado de Minas Gerais) for their financial support.

\section{References}

Acres, G. (2001). Recent advances in fuel cell technology and its applications. Journal of Power Sources, Vol. 100, No. (November 2001), pp. (60-66), ISSN 0378-7753

Amado, R. S.; Malta, L. F. B; Garrido, F. M. S.; Medeiros, M. E. Solid oxide fuel cells: materials, components and configurations. Química Nova, Vol. 30, No. 1, pp. (189197) ISSN 0100-4042

Badwal, S.P.S. (2001). Stability of solid oxide fuel cell components. Solid State Ionics, Vol.143, No. 1-4 (June 2001), pp.(39-46), ISSN 0167-2738

Bao,W.; Qibing, C.; Guangyao, M. (2005). Effect of NiO/YSZ compositions on the cosintering process of anode-supported fuel cell. Journal of Membrance Science,Vol. 259, No.1-2, (August 2005), pp. (103-109), ISSN 0376-7388 
Belardi, R.M.; Brant, M. C. ;Matencio, T.; Domingues (2009). Electrical study of cathodic activation and relaxation of $\mathrm{La}_{0,80} \mathrm{Sr}_{0,20} \mathrm{MnO}_{3}$. Ionics, Vol. 15, No.2,(July, 2009), pp.(227-232), ISSN 0947-7047

Benyoucef, A.; Klein, D.; Coddet, C.; Benyoucef, B. (2008). Development and characterisation of $(\mathrm{Ni}, \mathrm{Cu}, \mathrm{Co})-\mathrm{YSZ}$ and $\mathrm{Cu}-\mathrm{Co}-\mathrm{YSZ}$ cermets anode materials for SOFC application. Surface and Coating Technology. Vol. 202, No.10, (February 2008),pp. (2202-2207), ISSN 0257-8972

Brant, M. C. ;Matencio, T.; Dessemond, L. ; Domingues (2001), Fernandes, R. Z; Domingues, R.Z. (2001). Electrical and microstructural aging of porous Lanthanum Strontium Manganite/Yttria-doped cubic Zirconia Electrodes. Chemistry of Materials, USA American Chemical Society, Vol. 13, No. 11, (October 2001) pp. (3954-3961), 2001. ISSN (electronic): 1520-5002

Brant, M. C. ;Matencio, T.; Dessemond, L. ; Domingues (2006), Electrical degradation of porous and dense LSM/YSZ interface. Solid State Ionics, Vol. 177, No. 9-10, (March, 2006), pp. (915-921). ISSN 0167-2738

Chen, W.; Wen,T.;Nie, H.; Zheng, R. (2003) Study of $\mathrm{Ln}_{0.6} \mathrm{Sr}_{0.4} \mathrm{Co}_{0.8} \mathrm{Mn}_{0.2} \mathrm{O}_{3-\delta}$ (Ln=La, Gd, Sm or $\mathrm{Nd}$ ) as the cathode materials for intermediate temperature SOFC. Materials Reserch Bulletin, Vol. 38, No. 8, (July 2003), pp. (1319-1328), ISSN 0025-5408

Chen, J.; Liang, F.; Yan, D.; Pu, J.; Chi, B.; Jiang, S. P.; Jian, L.(2010) . Performance of largescale anode-supported solid oxide fuel cells with impregnated $\mathrm{La}_{0.6} \mathrm{Sr}_{0.4} \mathrm{Co}_{0.2} \mathrm{Fe}_{0.8} \mathrm{O}_{3}-\delta+\mathrm{Y}_{2} \mathrm{O}_{3}$ stabilized $\mathrm{ZrO}_{2}$ composite cathodes. Journal of Power Sources, Vol. 195, No. 16, (August 2010), pp. (5201-5205), ISSN 0378-7753

Charpentier, P.; Fragnaud, P.; Schleich, D. M.; Gehain, E. (2000). Preparation of thin film SOFCs working at reduced temperature. Solid State Ionics, Vol. 135, No. 1-4 (November 2000), pp.(373-380), ISSN 0167-2738

Ding, J.; Liu, J. (2008). An anode-supported solid oxide fuel cell with spray-coated yttriastabilized zirconia (YSZ) electrolyte film. Solid State Ionics, Vol. 179, No. 21-26, (September 2008), pp. (1246-1249), ISSN 0167-2738

Dutta, A.; Mukhopadhyay, J.; Basu, R.N. (2009). Combustion synthesis and characterization of LSCF-based materials as cathode of intermediate temperature solid oxide fuel cells. Journal of the European Ceramic Society. Vol. 29, No. 10, (July 2009), pp. (20032011), ISSN 0955-2219

EG\&G Technical services. (Ed(s).). (2000). Fuel Cell Handbook (5th), Parsons, Inc., ISBN 1603220178, Morgantown, West Virginia, EUA

Fabbri, E.; Pergolesi, D.; D’Epifanio, A.; Bartolomeo, E. D.; Balestrino, G.; Licoccia, S.; Traversa, E. 2008. Design and fabrication of a chemically-stable proton conductor bilayer electrolyte for intermediate temperature solid oxide fuel cells (IT-SOFCs). Energy \& Enviromental Science, Vol. 1, No. 3, (September 2008), pp. (355-359), ISSN 17545692

Fan, B.; Liu, X. (2009). A-deficit LSCF for intermediate temperature solid oxide fuel cells. Solid State Ionics, Vol. 180, No. 14-16, (June 2009), pp. (973-977), ISSN 0167-2738

Faro, M. L.; Rosa, D. L.; Antonucci, V.; Arico, A. S. (2009). Intermediate temperature solid oxide fuel cell electrolytes. Journal of the Indian Institute of Science, Vol. 89, No.4, (October-December 2009), pp. (363-381), ISSN 09704140 
Fergus, J.; Hui, Rob.; Li, X.; Wilkinson, D.P.; Zhang, J. Jeffrey (Ed(s)) (2009) .Solid oxide fuel cells : materials properties and performance, CRC Press, ISBN 978-1-4200-8883-0, London, NY.

Florio, D. Z. de; Fonseca, F. C.; Muccillo, E. N. S.; Muccillo, R. (2004). Ceramic materials for fuel cells. Cerâmica. Vol. 50, No. 316, (October -December 2004), pp. (275-290), INSS 0366-6913

Fonseca, C. G.; Basaglia, R.M.F; Brant, M. C.; Matencio, T.; Domingues, R. D. (2009). Study of the rheological behavior of an anode slurry and the microstructural properties of an anode functional film obtained by spray coating. Powder Technology, Vol. 192, No.3, (June 2009), pp. (352-358), ISSN 0032-5910

Guarany, C. A. (December 2008). Estruturas ferroelétricas, In: Ferroelétricos.com, 21.03.2011, Available from <http://ferroeletricos.com/perovskita.html>

Hibino, T.; Hashimoto, A.; Yano, M.; Suzuki, M.; Sano, M (2003). Ru-catalyzed anode materials for direct hydrocarbon SOFCs. Electrochimica Acta, Vol.48, No.17, (July 2003), pp. 2531-2537, ISSN 0013-4686

Huang, T. J; Chou, C. L.; Chen, W. J.; Huang, M. C.(2009) Coal syngas reactivity over Niadded LSCF-GDC anode of solid oxide fuel cells. Electrochemistry Communications, Vol. 11, No. 2, (February 2009), pp. (294-297), ISSN 1388-2481

Hui, S.; Petric, A. Evaluation of yttrium-doped $\mathrm{SrTiO}_{3}$ as an anode for solid oxide fuel cells. Journal of the European Ceramic Society. Vol. 22, No. 9-10, ( September 2002), pp. (1673-1681) , ISSN 0955-2219

Jiang, S. P. (2002). A comparison of $\mathrm{O} 2$ reduction reactions on porous (La,Sr)MnO3 and $(\mathrm{La}, \mathrm{Sr})(\mathrm{Co}, \mathrm{Fe}) \mathrm{O} 3$ electrodes. Solid State Ionics, Vol.146, No. 1-2.,(January 2002), pp. (1-22), ISSN 0167-2738

Kenjo, T.; Nishiya, M. (2002) $\mathrm{LaMnO}_{3}$ air cathodes containing $\mathrm{ZrO}_{2}$ electrolyte for high temperature solid oxide fuel cells. Solid State Ionics, Vol. 57, No. 3-4, (October 1992), pp. (295-302), ISSN 0167-2738

Kharton, V. V.; Marques, F. M. B.; Atkinson, A. (2004). Transport properties of solid oxide electrolyte ceramics: a brief review. Solid State Ionics, Vol. 174, No. 1-4, (October 2004), pp. (135-149), ISSN 0167-2738

Koide, H., Someya, Y., Yoshida, T.; Maruyama, T., (2000). Properties of Ni/YSZ cermet as anode for SOFC. Solid State Ionics, Vol.132,No.3-5, (July, 2000) pp.(253-260), ISSN 0167-2738

Liu, J.; Barnett, S. A. (2002). Thin Yttrium Stabilized zircônia electrolyte solid oxide fuel cells by centrifuge casting. Journal of the American Ceramic Society, Vol. 85, No. 12, (December 2002), pp. (3096-3098), ISSN 15512916

Liu, Y.; Hashimoto, s.; Nishino, H.; Takei, K.; Mori, M. (2007) Fabrication and characterization of a co-fired $\mathrm{La}_{0.6} \mathrm{Sr}_{0.4} \mathrm{Co}_{0.2} \mathrm{Fe}_{0.8} \mathrm{O}_{3-\delta}$ cathode-supported $\mathrm{Ce}_{0.9} \mathrm{Gd}_{0.1} \mathrm{O}_{1.95}$ thin-film for IT-SOFCs. Journal of Power Sources. Vol. 164, No. 1,(January 2007), pp. 56-64, ISSN 0378-7753

Lu, Z.; Zhou, X.-d.; Fisher, D.; Templeton, J.; Stevenson, J.; Wu, N.; Ignatiev, A. (2010). Enhanced performance of an anode-supported YSZ thin electrolyte fuel cell with a laser-deposited Sm0.2Ce0.8O1.9 interlayer. Electrochemistry Communications, Vol. 12, No. 2, (February 2010), pp. (179-182), ISSN: 1388-2481 
Maiti, A. K.; Rajende, B. (2002). Terpineol as a dispersant for tape casting yttria stabilized zirconia powder. Materials Science and engineering A, Vol. 333, No. 1-2, (August 2002), pp. (35-40), ISSN 0921-5093

Martins, R. F.; Brant, M. C.; Domingues, R. Z.; Paniago, R. M.; Sapag, K.; Matencio, T. (2009). Synthesis and characterization of NiO-YSZ for SOFCs, Materials Research Bulletin, Vol. 44, No. 2, (February 2009), pp. 451-456, ISSN 0025-5408

Matsuda, M.; Hosomia, T.; Murata, K.; Fukui, T.; Miyake, M. (2007). Fabrication of bilayered YSZ/SDC electrolyte film by electrophoretic deposition for reduced-temperature operating anode-supported SOFC. Journal of Power Sources, Vol. 165, No. 1, (February 2007), pp. (102-107), ISSN 0378-7753

Matsuzaki, Y; Yasuda, I.(2007). The poisoning effect of sulfur-containing impurity gas on a SOFC anode: Part I. Dependence on temperature, time, and impurity concentration. Journal of Power Sources, Vol. 171, No. 2, (September 2007), pp. (247-260), ISSN 03787753

McIntosh, s.; Vohs, J.M.; Gorte, R.J.(2002). An examination of lanthanide additives on the performance of Cu-YSZ cermet anodes. Electrochemica Acta, Vol. 47, No. 22-23, (August 2002), pp. (3815-3821), ISSN 0013-4686

Mukherjee, A.; Maiti, B.; Das Sharma, A.; Basu, R. N.; Maiti, H. S. (2001). Correlation between slurry rheology, green density and sintered density of tape cast yttria stabilised zirconia. Ceramics International, Vol. 27, No. 7, (August 2001), pp. (731739), ISSN 0272-8842

Murata, K.; Fukui, T.; Abe, H.; Naito, M.; Nogi, K. (2005). Morphology control of $\mathrm{La}(\mathrm{Sr}) \mathrm{Fe}(\mathrm{Co}) \mathrm{O}_{3-a}$ cathodes for IT-SOFCs. Journal of Power Sources. Vol. 145, no. 2, (August 2005), pp. 257-261, ISSN 0378-7753

Mitchell, B. S. (2004). An Introduction to Materials Engineering. and Science for Chemical and Materials Engineers, Jonh Wiler \& Sons, Inc., Hoboken, ISBN 0-471-43623-2, New Jersey, EUA

Nascimento, A. C; Basaglia, R. M. F.; Cunha, F. T. A; Fonseca, C. G; Brant, M. C; Matencio, T.; Domingues, R. Z. (2009) Correlation between yttria stabilized zirconia particle size and morphological properties of NiO-YSZ films prepared by spray coating process. Ceramics International, Vol. 35, No. 8, (December 2009),pp. (3421-3425), ISSN 0272-8842

Nesaraj, S. A. (2010). Recent developments in solid oxide fuel cell technology - a review. Journal of Scientific and Industrial Research, Vol. 69, No. 3, (March 2010), pp. (169176), ISSN:0022-4456

Perednis, D.; Gauckler. L. J. (2004). Solid oxide fuel cells with electrolytes prepared via spray pyrolysis. Solid State Ionics, Vol. 166, No. 3-4, (January 2004), pp. (229-239), ISSN 0167-2738

Petric, A.; Huang, P.; Tiet, F. (2000) Evaluation of La-Sr-Co-Fe-O perovskites for solid oxide fuel cells and gas separation membranes. Solid State Ionics, Vol. 135, No. 1-4, (November 2000), pp. (719-725), ISSN 0167-2738

Ramanathan, S.; Krishna Kumar, K. P.; DE, P. K.; Banerjee, S. (2005). Role of dispersion conditions on grindability of yttria stabilized zirconia (YSZ) powders, Bull. Mater. Sci., Vol. 28, No. 2, (April 2005), pp. (109-114), ISSN: 0250-4707 
Raza, R.; Wang, X.; Ma, Y.; Liu, X.; Zhu, B. (2010). Improved ceria-carbonate composite electrolytes. International Journal of Hydrogen Energy, Vol. 35, No.7, (April 2010), pp. (2684-2688), ISSN 0360-3199

Ringuede, A.; Labrincha, J.A.; Frade, J.r. (2001). A combustion synthesis method to obtain alternative cermet materials for SOFC anodes. Solid State Ionics. Vol. 141-142,(May 2001), pp. (549-557), ISSN 0167-2738

Ruiz-Morales, J.C., Canales-Vázquez, J.; Peña-Martínez, J.; López, D. M. ; Núñez, P. (2006). On the simultaneous use of $\mathrm{La}_{0.75} \mathrm{Sr}_{0.25} \mathrm{Cr}_{0.5} \mathrm{Mn}_{0.5} \mathrm{O}_{3-\delta}$ as both anode and cathode material with improved microstructure in solid oxide fuel cells, Electrochemical Acta, Vol. 52, No.1 (October 2006), pp. (278-284), ISSN 0013-4686.

Sanson, A.; Pinasco, P.; Ronconi, E. Influence of pore formers on slurry composition and microstructure of tape cast supporting anodes for SOFCs (2008). Journal of the European Ceramic Society, Vol. 28, No. 6, (February 2008), pp. (1221-1226), ISSN 09552219

Santillán, M. J.; Caneiro, A.; Quaranta, N.; Boccaccini, A. R. (2009). Electrophoretic deposition of $\mathrm{La}_{0.6} \mathrm{Sr}_{0.4} \mathrm{Co}_{0.8} \mathrm{Fe}_{0.2} \mathrm{O}_{3-\delta}$ cathodes on $\mathrm{Ce}_{0.9} \mathrm{Gd}_{0.1} \mathrm{O}_{1.95}$ substrates for intermediate temperature solid oxide fuel cell (IT-SOFC). Journal of the European Ceramic Society, Vol. 29, No. 6, (April 2009), pp. (1125-1132), ISSN 0955-2219

Savaniu, C.D.; Irvine, J.T.S. La-doped $\mathrm{SrTiO}_{3}$ as anode material for IT-SOFC (2010). Solid state Ionics, Article in Press, ISSN 0167-2738

Sin, A; Kopnin, E.; Dubitsky, Y.; Zaopo, A.; Aricò, A. S.; Gullo, L. R.; La Rosa, D.; Antonucci, V. (2005) Stabilisation of composite LSFCO-GDC based anodes for methane oxidation in solid oxide fuel cells. Journal of Power Sources, Vol. 145, No. 1, (July 2005), pp. (68-73), ISSN 0378-7753

Singhal, S.C.\& Kendall, K. (2003). High temperature solid oxide fuel cells: fundamentals, design, and applications: Elsevier Science Ltd, ISBN 1-85617-387-9, Oxford, UK.

Steele, B. C. H. (2000). Appraisal of $\mathrm{Ce}_{1-\mathrm{y}} \mathrm{Gd}_{\mathrm{y}} \mathrm{O}_{2-\mathrm{y} / 2}$ electrolytes for IT-SOFC operation at 500 oC. Solid State Ionics, Vol. 129, No. 1-4, (April 2000), pp. (95-110), ISSN 0167-2738

Sun,C.; Stimming, U.; Sun,C.; Stimming, U. (2007). Recent anode advances in solid oxide fuel cells. Journal of Power Sources, Vol. 171, No.(2), (September 2007), pp. (247-260), ISSN 0378-7753

Sun, C.; Hui, R.; Roller, J. (2010) Cathode materials for solid oxide fuel cells: a review. J Solid State Electrochem, Vol. 14,No (7), (July 2010), pp.(1125-1144), ISSN: 1432-8488 (print version)

Tai,L.-W.; M. M. Nasrallah, M.M.; Anderson, H.U.; Sparlin, D.M.; Sehlin, S. R (1995). Structure and electrical properties of $\mathrm{La}_{1-x} \mathrm{Sr}_{x} \mathrm{CO}_{1-y} \mathrm{Fe}_{y} \mathrm{O}_{3}$. Part 1. The system $\mathrm{La}_{0.8} \mathrm{Sr}_{0.2} \mathrm{Co}_{1-y} \mathrm{Fe}_{y} \mathrm{O}_{3}$.Solid State Ionics, Vo.1.76, No.3-4, (March 2000), pp (259-271), ISSN 0167-2738

Tarancón, A. (2009). Strategies for lowering solid oxide fuel cells operating temperature. Energies, Vol. 2, No. 4, (November 2009), pp. (1130-1150), ISSN 1996-1073

Tarôco, H.A.; Andrade, S. T. P; Brant, M. C.; Domingues, R. Z.; Matencio, T. (2009). Assembly and electrical characterization of solid oxide fuel cell stacks. Quim. Nova, Vol.32, No.5, pp. (1297-1305) ISSN 0100-4042

Teraoka, Y.; Nobunaga, T.; Okamoto, K.; Miura, N.;Yamazoe, N.;(1991). Influence of constituent metal cations in substituted $\mathrm{LaCoO}_{3}$ on mixed conductivity and oxygen 
permeability. Solid State Ionics, Vol. 48, No. 3-4, (November 1991), pp. (207-212), ISSN 0167-2738

Tietz, F.; Buchkremer H.-P.; Stöver D. (2002). Components manufacturing for solid oxide fuel cells. Solid State Ionics, Vol. 152-153, (December 2002), pp. (373-381), ISSN 01672738

Tietz, F.; Haanappel, V. A. C.; Maim A.; Mertens, J.; Stöver, D. (2006). Performance of LSCF cathodes in cell tests. Journal of Power Sources, Vol. 156, No. 1-19, (May 2006), pp. (20-22), ISSN 0378-7753

Tseng, W. J.; Chen,; C. N. (2003). Effect of polymeric dispersant on rheological behavior of nickel-terpineol suspensions. Materials Science and Engineering A, Vol. 347, No. 1-2, (April 2003), pp. (145-153), ISSN 0921-5093

Ullmann, H.; Trofimenko, N.;Tietz, F.; Stöver, D.; Ahmad-Khanlou A. (2000). Correlation between thermal expansion and oxide ion transport in mixed conducting perovskite-type oxides for SOFC cathodes. Solid State Ionics, Vol., No.1-2, (December 2000), pp. (79-90), ISSN 0167-2738

Uhlenbruck, S.; Moskalewicz, T.; Jordan, N.; Penkalla, H.-J.; Buchkremer, H. P. (2009). Element interdiffusion at electrolyte-cathode interfaces in ceramic hightemperature fuel cells. Solid State Ionics, Vol. 180, No. 4-5, (April 2009), pp. (418423), ISSN 0167-2738

Wincewicz, K.C.; Cooper; J. S. (2005). Taxonomies of SOFC material and manufacturing alternatives. Journal of Power Sources, Vol. 140, No.2, (February 2005) pp. 280-296, ISSN 0378-7753

Yamamoto, O.; Takeda, Y.; Kanno, R.; Noda,N. (1987). Perovskite-type oxides as oxygen electrodes for high temperature oxide fuel cells, Solid State Ionics. Vol. 22, No. 2-3 (January 1987), pp. (241-246), ISSN 0167-2738

Yoo, K.B.; Choi, G.M. LST-GDC composite anode on LaGaO3-based solid oxide fuel cell (2010). Solid State Ionics, Article in Press, ISSN 0167-2738

Zhu, w. Z.; Deevi, S. C.(2003). A review on the status of anode materials for solid oxide fuel cells. Materials Science and Engineering A, Vol. 362, No. 1-2, (December 2003), pp. (228-239), ISSN 0921-5093 


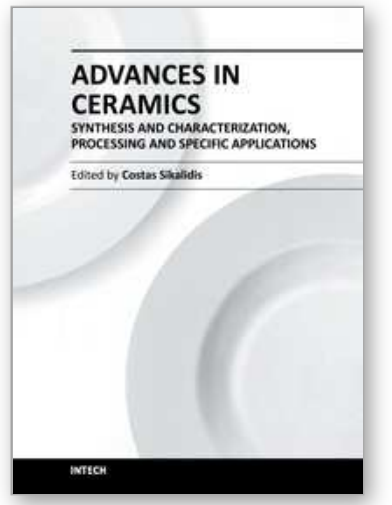

\author{
Advances in Ceramics - Synthesis and Characterization, \\ Processing and Specific Applications \\ Edited by Prof. Costas Sikalidis
}

ISBN 978-953-307-505-1

Hard cover, 520 pages

Publisher InTech

Published online 09, August, 2011

Published in print edition August, 2011

The current book contains twenty-two chapters and is divided into three sections. Section I consists of nine chapters which discuss synthesis through innovative as well as modified conventional techniques of certain advanced ceramics (e.g. target materials, high strength porous ceramics, optical and thermo-luminescent ceramics, ceramic powders and fibers) and their characterization using a combination of well known and advanced techniques. Section II is also composed of nine chapters, which are dealing with the aqueous processing of nitride ceramics, the shape and size optimization of ceramic components through design methodologies and manufacturing technologies, the sinterability and properties of $\mathrm{ZnNb}$ oxide ceramics, the grinding optimization, the redox behaviour of ceria based and related materials, the alloy reinforcement by ceramic particles addition, the sintering study through dihedral surface angle using AFM and the surface modification and properties induced by a laser beam in pressings of ceramic powders. Section III includes four chapters which are dealing with the deposition of ceramic powders for oxide fuel cells preparation, the perovskite type ceramics for solid fuel cells, the ceramics for laser applications and fabrication and the characterization and modeling of protonic ceramics.

\title{
How to reference
}

In order to correctly reference this scholarly work, feel free to copy and paste the following:

H. A. Taroco, J. A. F. Santos, R. Z. Domingues and T. Matencio (2011). Ceramic Materials for Solid Oxide Fuel Cells, Advances in Ceramics - Synthesis and Characterization, Processing and Specific Applications, Prof. Costas Sikalidis (Ed.), ISBN: 978-953-307-505-1, InTech, Available from:

http://www.intechopen.com/books/advances-in-ceramics-synthesis-and-characterization-processing-andspecific-applications/ceramic-materials-for-solid-oxide-fuel-cells

\section{INTECH}

open science | open minds

\author{
InTech Europe \\ University Campus STeP Ri \\ Slavka Krautzeka 83/A \\ 51000 Rijeka, Croatia \\ Phone: +385 (51) 770447 \\ Fax: +385 (51) 686166 \\ www.intechopen.com
}

\author{
InTech China \\ Unit 405, Office Block, Hotel Equatorial Shanghai \\ No.65, Yan An Road (West), Shanghai, 200040, China \\ 中国上海市延安西路65号上海国际贵都大饭店办公楼 405 单元 \\ Phone: +86-21-62489820 \\ Fax: +86-21-62489821
}


(C) 2011 The Author(s). Licensee IntechOpen. This chapter is distributed under the terms of the Creative Commons Attribution-NonCommercialShareAlike-3.0 License, which permits use, distribution and reproduction for non-commercial purposes, provided the original is properly cited and derivative works building on this content are distributed under the same license. 